\title{
Impact of nutrition on canine behaviour: current status and possible mechanisms
}

\author{
G. Bosch ${ }^{1}$, B. Beerda ${ }^{2}$, W. H. Hendriks ${ }^{1}$, A. F. B. van der Poel ${ }^{1}$ and M. W. A. Verstegen ${ }^{1}$ \\ ${ }^{1}$ Animal Nutrition Group, Animal Sciences Group, Wageningen University and Research Centre, PO Box 338, \\ 6700 AH Wageningen, The Netherlands \\ ${ }^{2}$ Animal Production Division, Animal Sciences Group, Wageningen University and Research Centre, PO Box 65, \\ 8200 AB Lelystad, The Netherlands
}

\begin{abstract}
Each year, millions of dogs worldwide are abandoned by their owners, relinquished to animal shelters, and euthanised because of behaviour problems. Nutrition is rarely considered as one of the possible contributing factors of problem behaviour. This contribution presents an overview of current knowledge on the influence of nutrition on canine behaviour and explores the underlying mechanisms by which diet may affect behaviour in animals. Behaviour is regulated by neurotransmitters and hormones, and changes in the availability of their precursors may influence behaviour. Tryptophan, the precursor of serotonin, may affect the incidence of aggression, selfmutilation and stress resistance. The latter may also be influenced by dietary tyrosine, a precursor to catecholamines. As diet composition, nutrient availability and nutrient interactions affect the availability of these precursors in the brain, behaviour or stress resistance may be affected. PUFA, especially DHA, have an important role as structural constituents in brain development, and dietary supply of $n-3$ and $n-6$ PUFA could modify aspects of the dopaminergic and serotonergic system and, consequently, cognitive performance and behaviour. Finally, persistent feeding motivation between meals can increase stereotyped behaviour and aggression and decrease resting time. This feeding motivation may be altered by dietary fibre content and source. At present, few studies have been conducted to evaluate the role of nutrition in canine (problem) behaviour through the above mentioned mechanisms. Studies that explore this relationship may help to improve the welfare of dogs and their owners.
\end{abstract}

\section{Dogs: Food: Nutrients: Behaviour}

\section{Introduction}

The domestic dog (Canis familiaris) is believed to have evolved from the grey wolf (C. lupis) as a separate species at least 15000 years ago and it is thought to be the first animal species to be domesticated by humans ${ }^{1,2}$. At the present time, as a result of selective breeding, approximately 400 distinct dog breeds are recognised worldwide, representing a large variation in body size and weight, with the latter ranging from 1 to $90 \mathrm{~kg}$. Initial functions of dogs such as hunting, shepherding and guarding have diminished gradually in importance in favour of the dog's role as a companion to humans ${ }^{3}$. Though most human-dog relationships are fulfilling, each year a large number of animals are abandoned by their owners or relinquished to animal shelters ${ }^{4}$. Aggression toward people and animals, running away, destructive behaviour, disobedience, house soiling and excessive barking are unwanted behaviours that make owners relinquish or abandon their $\operatorname{dogs}^{5}$. Although only $20 \%$ of the dogs in the US shelters are assigned by their owners for euthanasia ${ }^{6}$, a further $40 \%$ of dogs admitted are euthanised ${ }^{7}$. Of the sheltered dogs that are purchased by new owners, approximately $20 \%$ are returned to shelters ${ }^{6,7}$ and a large proportion of these animals are euthanised ${ }^{4}$. The number of dogs and cats euthanised annually in the USA is estimated to be between 5 and 17 million $^{8,9}$, with 3-6 million as a result of behaviour problems ${ }^{10}$. Strategies that combat problem behaviours in dogs will greatly benefit animal welfare. The behaviour of individual dogs is controlled by numerous factors and from studies in humans it can be derived that nutrition plays a role also. For example, diets rich in vitamins and minerals may decrease anti-social behaviour in schoolchildren ${ }^{11}$ and supplementation of vitamins, minerals and essential fatty acids

\footnotetext{
Abbreviations: DHA, docosahexaenoic acid; EPA, eicosapentaenoic acid; GLP-1, glucagon-like peptide-1; ISF, insoluble fibre; LNAA, large neutral amino acids; ME, metabolisable energy; PUFA, polyunsaturated fatty acid; PYY, peptide tyrosine tyrosine; SF, soluble fibre; VFA, volatile fatty acids.

*Corresponding author: Ir G. Bosch, fax +31 317 484260, email Guido.Bosch@wur.nl
} 
decreased anti-social behaviour, including violence, of young adult prisoners ${ }^{12}$. Dietary effects on behaviour have been investigated for anti-social aspects, but also for behavioural changes related to ageing and, in this, dogs have been used as a model for humans. Dogs develop similar cognitive deficits and neuropathology as can be seen in ageing humans and elderly suffering from dementia ${ }^{13}$. Milgram and co-workers initiated a series of experiments with young and aged beagle dogs to study dietary interventions on age-related cognitive decline. Results showed that canine food enriched with antioxidants and mitochondrial cofactors decreased the rate of cognitive decline in aged beagle dogs under laboratory conditions and improved age-related behavioural changes in older pet dogs held in home situations (for reviews, see Roudebush et al. ${ }^{14}$ and Zicker ${ }^{15}$ ). These findings demonstrate clearly that canine behaviour can be influenced by dietary components.

The present review presents an overview of our current knowledge on the influence of dietary macronutrient composition on the behaviour of dogs and explores the underlying mechanisms by which diet may affect behaviour. Findings from food-behaviour studies in dogs and other mammals are integrated to assess in what way problem behaviour in dogs may be reduced through dietary means.

\section{Effects of dietary amino acids and protein content on behaviour}

After ingestion, proteins are enzymically degraded and absorbed in the small intestine mainly as tripeptides, dipeptides and free amino acids. After hydrolysis of the peptides in the enterocytes, the free amino acids are transported through the portal vein to the liver. Amino acids are important constituents required for the synthesis of enzymes and other proteins, and used as precursors for the synthesis of neurotransmitters and hormones ${ }^{16}$. For example, serotonin, catecholamines, acetylcholine and histamine are metabolites from tryptophan, tyrosine, choline and histidine, respectively ${ }^{17}$. These neurotransmitter precursors (except for choline) are amino acids and are natural dietary constituents. Behaviour results from signal detection, transmission and processing in the (central) nervous system, which is accomplished and modulated by chemical messengers such as neurotransmitters and hormones. Changes in neurotransmitter precursors such as tryptophan and tyrosine are, therefore, likely to influence behaviour. The amount and timing of food intake, diet composition and digestibility are all factors that determine the availability of different amino acids, i.e. precursors of chemical messengers. Consequently, such factors may influence behaviour. The effects of tryptophan and tyrosine on behaviour will be discussed as these could be relatively potent modulators; for similar reports on choline, histidine and threonine, we refer to Young ${ }^{17}$.

\section{Findings and mechanisms in different mammals}

Tryptophan. A diet high in tryptophan has been shown to reduce mouse killing by rats ${ }^{18,19}$, reduce aggression in vervet monkeys $^{20}$, enhance exploratory behaviour in female silver foxes ${ }^{21}$ and reduce self-injurious behaviour in rhesus monkeys ${ }^{22}$. In contrast to the observed reductions in aggression in some experimental conditions, dietary supplementation of tryptophan has also been shown to increase territorial aggression in male mice ${ }^{23}$. Dietary tryptophan may also influence the resistance or tolerance to stress and, therefore, change the behavioural stress response. Koopmans et al. $^{24}$ reported enhanced recovery after social stress as measured by lower plasma cortisol and noradrenaline concentrations in pigs fed a surplus of dietary tryptophan compared with pigs fed diets containing a 'normal' concentration of tryptophan. In addition, supplementation of dietary tryptophan reduced plasma cortisol concentrations during a stress-inducing mental arithmetic task in healthy stress-vulnerable humans ${ }^{25}$. It was, therefore, suggested by Markus et al. ${ }^{25}$ that tryptophan supplementation above normal dietary concentrations could improve the ability of an individual to cope with stress. The effects of dietary tryptophan on stress resistance involve different pathways. In rats a variety of stressors, such as immobilisation, foot shock, and hypothermia, increase brain tryptophan and serotonin turnover ${ }^{26-29}$. Depressed humans show decreased plasma tryptophan concentrations in comparison with normal subjects ${ }^{30}$. It appears that initially stressors stimulate serotonin turnover, which over time may deplete serotonin (precursor) supplies and result in decreased serotonin (precursor) concentrations.

Quantitatively the most important pathway for tryptophan metabolism, after protein synthesis, is the kynurenine pathway which is responsible for over $90 \%$ of tryptophan catabolism $^{31}$. In humans, normally $1 \%$ of the available tryptophan is converted to serotonin which is mainly present in the gastrointestinal tract ${ }^{32}$. The first and rate-limiting step in the synthesis of serotonin is the hydroxylation of tryptophan to 5-hydroxytryptophan by the enzyme tryptophan hydroxylase (Fig. 1). Tryptophan hydroxylase is normally about half saturated with tryptophan ${ }^{33}$. Consequently, an increase in tryptophan in the brain, which increases serotonin synthesis and serotonergic neurotransmission $^{34}$, can maximally double serotonin synthesis. The second step in the synthesis of serotonin is the decarboxylation of 5-hydroxytryptophan to serotonin which is stored in vesicles in the nerve terminal were it is held before release. When serotonin is released into the synaptic cleft, serotonin can bind to different subtype receptors (for reviews, see Barnes \& Sharp ${ }^{35}$ and Hoyer et $a l^{36}$ ). Via binding to these different receptors, serotonin can produce many different effects on post-synaptic cells influencing various parts of the brain involved in controlling a variety of physiological functions including hormone releases, cardiovascular functioning, pain, appetite, and in general mood and behaviour ${ }^{35-37}$.

Tryptophan transport across the blood-brain barrier and metabolism is in part affected by animal factors such as breed $^{38}$, sex ${ }^{21,39}$, social status ${ }^{40,41}$, age activity $^{43}$ and level of arousal ${ }^{44}$. The availability of dietary tryptophan to the brain is largely dependent on the composition of the ingested diet. Tryptophan is found in nearly all protein-containing foods where it is found in a lower concentration compared with the other large neutral amino acids (LNAA) tyrosine, phenylalanine, leucine, isoleucine 


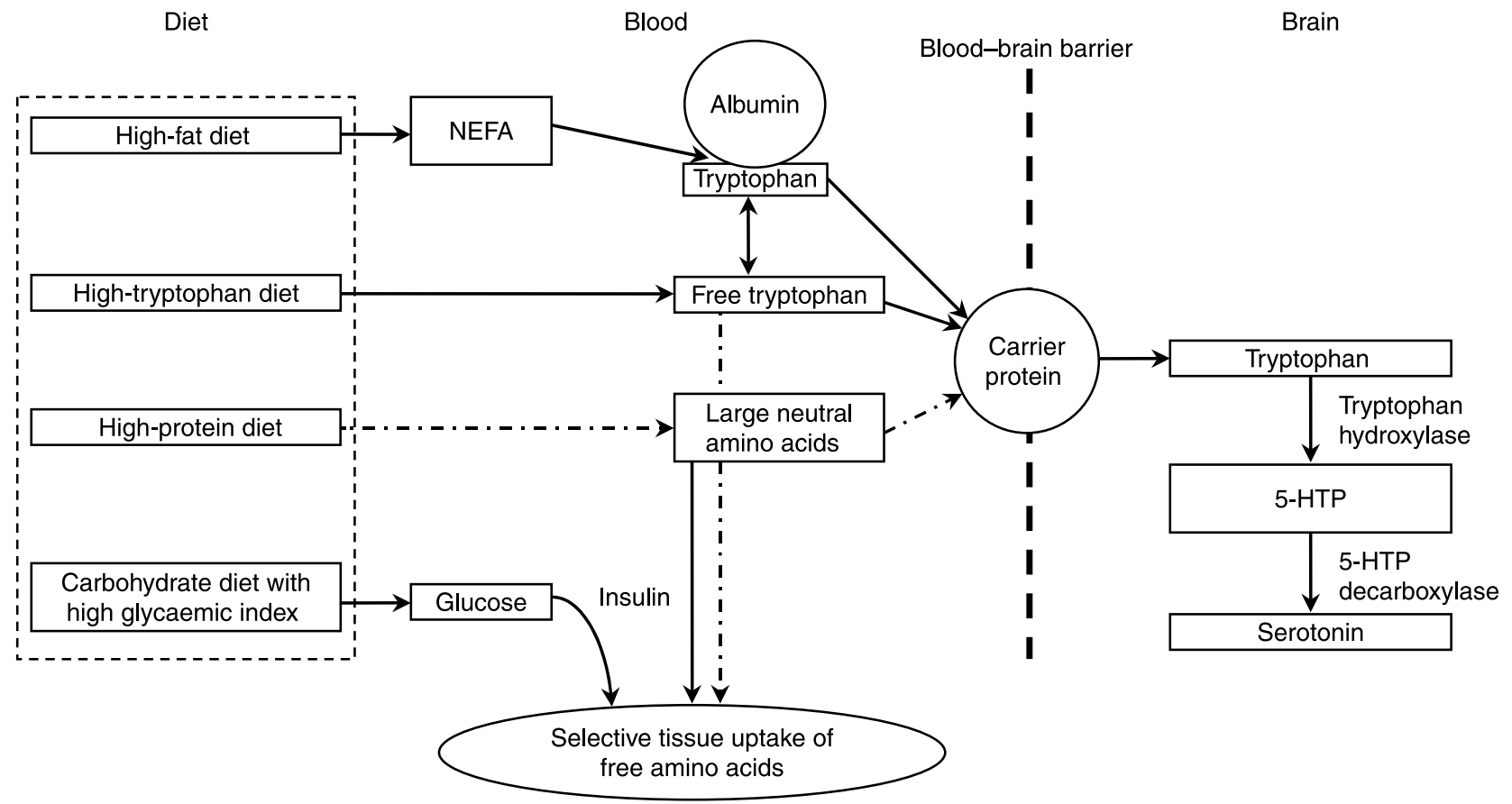

Fig. 1. Effects of dietary characteristics on tryptophan uptake by the central nervous system and synthesis of serotonin from brain tryptophan (adapted from Grimmett \& Sillence ${ }^{185}$ with modifications). (-.-), Factors that may ultimately decrease brain tryptophan; 5-HTP, 5-hydroxytryptophan; NEFA, non-esterified fatty acids.

and valine ${ }^{45}$. For access into the brain, tryptophan shares the same carrier as other LNAA for transport across the bloodbrain barrier ${ }^{34}$. Central tryptophan concentrations can either be increased by increasing plasma tryptophan or by lowering plasma concentrations of LNAA ${ }^{34,46}$. As tryptophan is normally present in only small concentrations in dietary protein compared with other LNAA, the consumption of a meal high in protein will decrease the ratio of tryptophan to other $\mathrm{LNAA}^{47}$ and thereby potentially lower serotonin synthesis.

The fraction of unbound tryptophan as compared with that bound to albumin is another factor that may influence tryptophan availability to the brain $^{48}$. In mammals, approximately $80-90 \%$ of all tryptophan molecules in the blood are bound to serum albumin ${ }^{49}$. It has been suggested that the majority of the albumin-bound tryptophan is available for passage across the blood-brain barrier ${ }^{46,50}$, but possibly the concentration of circulating free tryptophan may be especially important ${ }^{48}$. According to Chaouloff ${ }^{48}$, three factors affect circulating free and bound tryptophan concentrations: (i) the rate of lipolysis because blood nonesterified fatty acids displace tryptophan from its binding to albumin $^{51}$; (ii) the activity of tryptophan 2,3-dioxygenase, the rate-limiting enzyme in tryptophan detoxication through the kynurenine pathway - activation (inactivation) of this enzyme decreases (increases) circulating blood tryptophan levels ${ }^{52}$; (iii) uptake into peripheral and central tissues. Carbohydrate-induced insulin rises facilitate the uptake of most LNAA into skeletal muscle, but not tryptophan bound to albumin ${ }^{53,54}$. Consequently, the ratio of tryptophan relative to LNAA increases. This results in a competitive advantage of tryptophan over LNAA for uptake at the blood-brain barrier. However, as little as $2-4 \%$ of the energy of a meal as protein seems to prevent this increased availability of tryptophan ${ }^{31,55}$.

Tyrosine. In rats, a high-tyrosine diet prevents adverse behavioural and neurochemical effects (for example, immobility during a swim test, depletion of brain noradrenaline) of various acute stressors including hypothermia ${ }^{56}$, restraint and tail-shock ${ }^{57-59}$. Human studies also suggest beneficial effects of tyrosine under conditions of stress (for reviews, see Lieberman ${ }^{60}$ and Young ${ }^{17}$ ).

Tyrosine, which can be synthesised from phenylalanine, is the direct precursor for the catecholamines dopamine, noradrenaline and adrenaline ${ }^{32}$. Dopamine can be synthesised from tyrosine in neurons in two steps. The first and rate-limiting step is the conversion of tyrosine to dihydroxyphenylalanine by the enzyme tyrosine hydroxylase. In rats, central tyrosine hydroxylase is approximately $75 \%$ saturated with tyrosine ${ }^{33}$. In the second step, dihydroxyphenylalanine is decarboxylated to dopamine which can be used as an endproduct (neurotransmitter) in neurons or further converted to noradrenaline or adrenaline ${ }^{61}$. Like tryptophan, tyrosine competes with other LNAA at the blood-brain barrier for entry into the brain $^{34}$ and is taken up into skeletal muscle under the influence of insulin ${ }^{53,54}$. In diets, tyrosine is typically available in much higher concentrations compared with tryptophan and high-protein meals will typically raise tyrosine concentrations in the brain, but will lower the concentration of tryptophan ${ }^{62}$. Catecholamines play a key role in a variety of behavioural, neuroendocrine and cardiovascular responses during stress $^{60}$. Increases in 
brain tyrosine have little or no effect on catecholamine synthesis ${ }^{17}$, but the situation may be different during stress when brain noradrenaline turnover increases and noradrenaline concentrations decrease ${ }^{57,63}$. An enhanced noradrenergic activity is part of a normal adaptive stress response ${ }^{64}$. In stressed rats (tail-shock), ingestion of a high-tyrosine diet reversed the post-stress decline in brain noradrenaline and attenuated behaviour changes, i.e. decreased locomotion, standing on hind legs, hole-poking in a novel open field ${ }^{57}$. This suggests that a high-tyrosine diet may be beneficial during severe stress, as it prevents depletion of the substrate required for catecholamine synthesis in times of high catecholaminergic activity and demand.

\section{Findings in $\operatorname{dog} s$}

Studies on the effects of tryptophan or tyrosine on behaviour in dogs seem to be limited to one. DeNapoli et al. ${ }^{65}$ formulated diets with high or low protein content (approximately 310 or $190 \mathrm{~g}$ crude protein $/ \mathrm{kg}$, respectively) and with or without tryptophan supplementation $(1.45 \mathrm{~g} / \mathrm{kg})$ in order to provide varying tryptophan contents and tryptophan:LNAA ratios (Table 1). Each of the four diets was fed in random order for 1 week to thirty-three privately owned dogs that displayed a high territorial aggression, dominance aggression or hyperactivity. There was no effect of dietary protein or tryptophan content on the behavioural scores within each group of problem behaviour. However, when the groups of dogs were analysed as one study population a lower territorial aggression score was obtained for dogs fed the high-tryptophan diet compared with dogs fed the low-tryptophan diet, but only when fed a low-protein diet. In addition, dogs fed the high-protein diet without tryptophan supplementation showed a higher dominance aggression score compared with dogs on the other dietary treatments.

Three studies in literature have reported that low-protein diets decreased aggression in dogs, though these were not performed under controlled experimental conditions. In a study with seven aggressive golden retrievers held at inhome living conditions, incidences of aggression as reported by their owners immediately decreased after the introduction of a low-protein diet $\left(15-18 \%\right.$ of total energy ${ }^{66}$. Unfortunately, neither the composition of the experimental diet nor the composition(s) of the $\operatorname{diet}(\mathrm{s})$ before the dietary intervention were reported. The reduction in aggressive incidences, however, was only sustained in three dogs; two dogs deteriorated again in their behaviour and contact was lost with the remaining two clients. In another study, twelve dogs that exhibited either high territorial aggression, dominance aggression or hyperactivity and fourteen control dogs were fed each of three diets varying in protein content (180, 250 and $310 \mathrm{~g}$ crude protein/kg DM) for 2 weeks at in-home living situations ${ }^{67}$. The low-protein diet and medium-protein diet decreased territorial aggression scores compared with the high-protein diet. No effects of dietary protein content in dogs with dominance aggression or hyperactivity were found. Additional behavioural analysis of the group of dogs demonstrating territorial aggression revealed that five of these dogs showed dominance-related

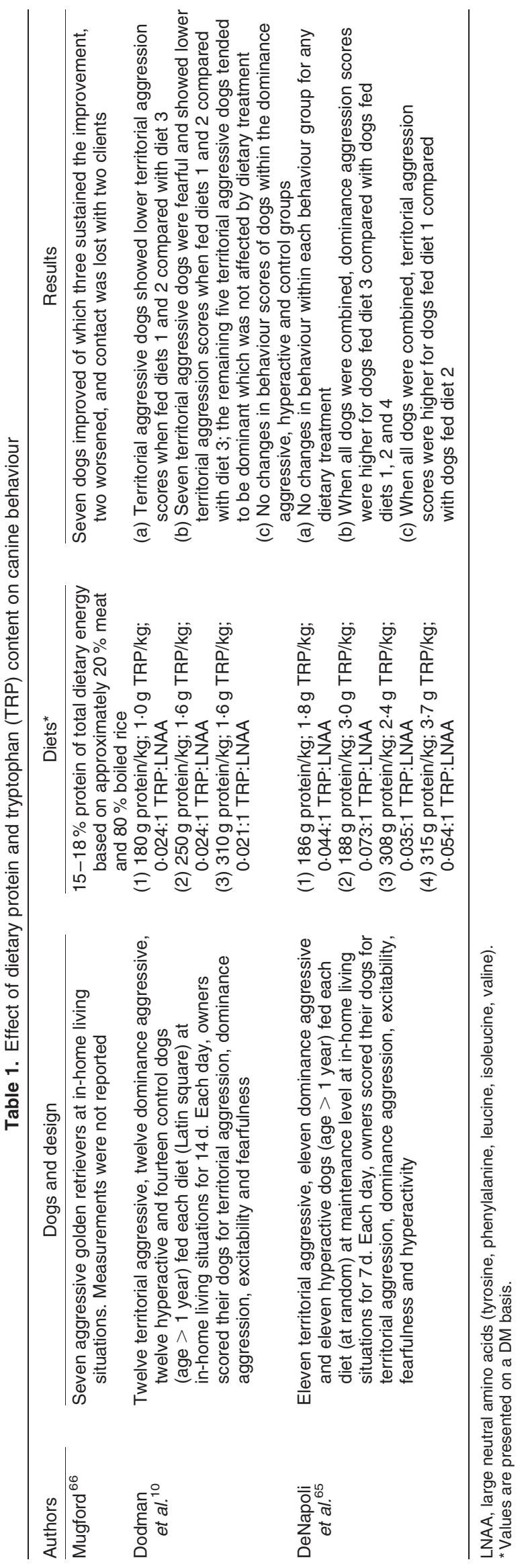


territorial aggression, whereas the other seven dogs showed fear-related territorial aggression. In the latter dogs, territorial aggression decreased when fed the lowprotein diet.

For adult dogs fed at maintenance, the minimal dietary tryptophan requirements are currently set at $0.0669 \mathrm{~g} / 1000 \mathrm{~kJ}(0.28 \mathrm{~g} / 1000 \mathrm{kcal})$ metabolisable energy (ME) with a tryptophan:LNAA ratio of 0.061:1 and for tyrosine and phenylalanine the minimal dietary requirements are $0.3537 \mathrm{~g} / 1000 \mathrm{~kJ}(1.48 \mathrm{~g} / 1000 \mathrm{kcal}) \mathrm{ME}^{68}$. The Association of American Feed Control Officials $(\mathrm{AAFCO})^{69}$ has minimum dietary requirements for these nutrients which are slightly higher $(0.1099$ and $0.4995 \mathrm{~g} /$ $1000 \mathrm{~kJ}(0.46$ and $2.09 \mathrm{~g} / 1000 \mathrm{kcal}) \mathrm{ME}$, respectively) in order to account for the lower digestibility and availability of nutrients in commercial canine foods compared with semi-synthetic diets. Nutritional guidelines for humans ${ }^{12}$ and dogs rarely take behaviour into account as a response criterion, something which has been criticised ${ }^{70,71}$. The minimum quantity of tryptophan in a commercial canine dry expanded diet that has passed a maintenance AAFCO feeding protocol has been reported to be $0.0502 \mathrm{~g} / 1000 \mathrm{~kJ}$ $(0.21 \mathrm{~g} / 1000 \mathrm{kcal}) \mathrm{ME}^{68}$. The criteria for passing an AAFCO maintenance feeding protocol however, do not take into account animal behaviour. It is unknown if the minimal amount of tryptophan in typical dog foods meets the requirements of the wide variety of dogs, for example, from emotionally stable to anxious individuals, under different conditions, for example, from stress-free to stressful. Both excessive intake and a deficiency of tryptophan are detrimental to the health of an animal ${ }^{31}$ and are likely to affect behaviour. In horses, a dose of $0.1 \mathrm{mg} / \mathrm{kg}$ body weight appears to be too low, causing mild excitation $^{38}$. In humans, the most common side effect of overfeeding precursors of neurotransmitters has been reported to be nausea ${ }^{17}$. There are currently no requirement estimates for the maximum amount of tryptophan in canine food and it remains to be determined how high-tryptophan diets affect the health of dogs and their behaviour in the long term.

\section{Effects of dietary lipids on behaviour}

Lipids have various functions, such as constituents of cellular membranes, precursors for chemical messengers (for example, steroid hormones) and their use as an energy source or stored in the body as adipose tissue. After adipose tissue, the central nervous system has the greatest concentration of lipids ${ }^{72}$. The structural constituents in the grey matter of the brain and retinal tissues in mammals are derived from dietary linoleic acid $(18: 2 n-6)$ and $\alpha$-linolenic acid (18:3n-3). Both are polyunsaturated fatty acids (PUFA) and can be metabolised to long-chain PUFA by sequential alternating enzymic desaturation and elongation. Linoleic acid can be metabolised to arachidonic acid (20:4n-6) which can be further metabolised to docosapentaenoic acid (22:5n-6). The enzymic desaturation and elongation of $\alpha$-linolenic acid yields eicosapentaenoic acid (EPA) (20:5n-3) which can be further metabolised to docosahexaenoic acid (DHA) $(22: 6 n-3)^{73}$.

\section{Findings and mechanisms in different mammals}

There is ample scientific literature available in which the effects of both dietary deficiency and supplementation of PUFA on animal performance in cognitive or behavioural tests are evaluated (for reviews, see Wainwright ${ }^{74}$ and McCann \& Ames $^{75}$ ). For example, the learning ability of rodents decreased when fed $n-3$ fatty-acid-deficient $\operatorname{diets}^{76,77}$ and increased when fed DHA-supplemented diets $^{78}$ compared with rodents fed diets adequate in $n-3$ fatty acid concentrations. Other studies, however, did not find affects of dietary $n$-3 PUFA manipulation on learning performance as tested with a Morris water-maze in rats ${ }^{79}$ or mice ${ }^{80}$. Dietary PUFA seem to affect animal cognition but can also cause behavioural changes. Rats fed $n-3$ PUFA-deficient diets showed increased aggression scores in a resident intruder test ${ }^{81}$ and increased expression of stress-related behaviours during several stress tests ${ }^{82}$ compared with male rats fed adequate amounts of $n-3$ PUFA. Similarly, anxiety was found to be increased in mice fed a diet deficient in $n-3$ PUFA $^{83}$, though others did not observe any effects of dietary PUFA on anxiety in mice $^{84}$ or rats ${ }^{85}$.

The dopaminergic and serotonergic systems in the brain are known to play important roles in learning, emotions, and impulse control ${ }^{37,86-90}$, which makes it tempting to assume that the effects of PUFA on behaviour run through these systems. Indeed, both systems are known to be influenced by PUFA. Rats deficient in $n-3$ PUFA compared with rats fed diets with $\alpha$-linolenic acid showed a reduction in dopamine concentration in the frontal cortex ${ }^{91-94}$ and an increase in dopamine concentration in the nucleus accumbens $^{93}$ but no effects in the striatum ${ }^{91,92}$. In the frontal cortex of these animals the rate of dopamine synthesis and breakdown mediated by monoamine oxidase was not affected ${ }^{92,94}$ and the reduced concentrations may have been linked to the reduced dopaminergic storage pools ${ }^{94,95}$. Changes in dopamine concentrations were followed by changes in number of $\mathrm{D}_{2}$ receptors ${ }^{94}$. n-3 PUFA-deficient rats had a lower number of $\mathrm{D}_{2}$ receptors in the frontal cortex ${ }^{91,92,94}$ but higher in the nucleus accumbens ${ }^{93,94}$. Rats fed diets supplemented with EPA and DHA had an increased dopamine concentration and $\mathrm{D}_{2}$ binding possibly as a result of a reduction in monoamine oxidase activity in the frontal cortex compared with rats fed adequate amounts of PUFA ${ }^{85}$.

As for dopamine concentrations, frontal cortex serotonin concentrations were increased in rats fed diets supplemented with $n-3$ PUFA $^{85}$. In line with this, serotonin in the frontal cortex was reduced in piglets fed $n-3$ and $n-6$ PUFA-deficient formula for $18 \mathrm{~d}$ from birth compared with piglets fed formula supplemented with linoleic acid and $\alpha-$ linolenic acid and/or arachidonic acid and $\mathrm{DHA}^{96}$. The findings in the frontal cortex may not extrapolate to other brain areas. For example, in the hippocampus of 2-monthold rats fed an $n$-3 PUFA-deficient diet extracellular basal serotonin concentrations were increased ${ }^{97}$. This was probably due to reduced storage pools ${ }^{97}$, not due to decreased activity of monoamine oxidase ${ }^{98}$. Such effects of $n$-3 PUFA deficiency on serotonin concentrations are not found in all studies (for example, Delion et al. ${ }^{91,92}$ ). 
In addition to the observed changes in the dopaminergic and serotonergic systems in different brain regions, physical properties (for example, fluidity, permeability) of cerebral membranes may also mediate dietary effects on cognition and behaviour ${ }^{99}$. For example, chronic dietary deficiency in $n-3$ PUFA resulted in low concentrations of $n-3$ PUFA in the rat brain ${ }^{76,77}$ whereas diets high in EPA and DHA resulted in high concentrations of EPA and DHA in the brain of rats ${ }^{85,100,101}$. In addition, dietary $\alpha$-linolenic acid deficiency induces a more pronounced reduction in DHA concentrations in the frontal cortex than in the striatum and cerebellum $^{72,91}$. Besides changes in brain PUFA compositions, dietary PUFA may alter properties of the neuronal membrane, such as the activity of membrane-bound enzymes, receptors and ion channels ${ }^{102}$. These alterations may affect neurological functioning and may, therefore, also contribute to the observed changes in cognitive functioning and behaviour.

\section{Findings in dogs}

To the authors' knowledge, there are at this moment no scientific articles available regarding the influence of $n-3$ or $n$-6 PUFA deficiency or enrichment on canine behaviour or cognitive performance. Since DHA is essential for the development and function of the brain and retina ${ }^{73}$, its supply may affect neurological development in puppies. For example, low dietary concentrations of DHA during the gestation or lactation of bitches and dry diets for puppies depressed their retinal sensitivity ${ }^{103,104}$. Although the immediate connection between the cellular effects of DHA and visual sharpness and cognitive abilities in receiving dietary DHA still needs more support ${ }^{73}$, studies seem to emphasise the importance of DHA in the diet of bitches during gestation until weaning and the diet of puppies in order to ensure optimal neurological development. At present, there is no recommended allowance for DHA for both bitches in gestation and lactation or puppies, but the recommended allowance for $\alpha$-linoleic acid is $3.35 \mathrm{~g} /$ $1000 \mathrm{~kJ}(0.8 \mathrm{~g} / 1000 \mathrm{kcal}) \mathrm{ME}^{68}$. A diet high in $\alpha$-linolenic acid fed from breeding throughout lactation increased $\alpha$ linolenic acid concentration in milk but failed to do this for $\mathrm{DHA}^{105,106}$. In a recent study, puppies converted $\alpha$-linolenic acid to DHA during the first month of weaning but little conversion of $\alpha$-linolenic acid to DHA occurs after weaning $^{106}$. It seems that the capacity of puppies to synthesise DHA from dietary $\alpha$-linolenic acid or other $n-3$ fatty acid precursors is active for only a short time during the neonatal period and is decreased thereafter. The amount of dietary $\alpha$-linolenic acid for sufficient synthesis of DHA and the amount of DHA required for optimal neurological development in puppies still remain to be determined. Whether the provision of sufficient DHA for optimal neurological development in dogs also results in changes in the dopaminergic and serotonergic systems and subsequent effects in cognitive abilities or behaviour in later life remains to be confirmed.

Concerning commercial dog food, it seems likely that in dogs deficiencies of PUFA are rare as long as fat oxidation during process and storage of the food is limited ${ }^{107}$. Levels of PUFA, particularly the $n$ - 3 family, are nowadays higher in commercial dog food compared to foods of several years ago $^{108}$ (Delton-Vandenbroucke et al., 1998). However, the amount and ratio between $n-6$ and $n-3$ fatty acids may differ considerably between commercially available diets. The $n-6: n-3$ fatty acid ratio of twelve commercial dry dog foods was found to differ considerably, ranging from 17:1 to $5: 1^{109}$.

\section{Effects of dietary carbohydrates on behaviour}

Feeding of mammals is a discontinuous process in which periods of food consumption are interspersed with periods of non-eating ${ }^{110}$. Food intake behaviours are controlled by feelings of hunger ${ }^{11}$ and satiety ${ }^{110}$, but may be modulated by psychological and social factors ${ }^{112}$. Numerous central and peripheral signal molecules are involved in the regulation of eating (for reviews, see Bray ${ }^{113}$, de Graaf et al. ${ }^{114}$ and Strader \& Woods $\left.{ }^{115}\right)$. The rate and site of degradation of nutrients largely determines the postprandial physiological state of an animal and in this way the extent and duration of satiety and, therefore, behaviour. There is a wide variety of carbohydrates with different physical and chemical properties. These properties can affect the rate and site of degradation of these carbohydrates ${ }^{116}$. In singlestomached animals, degradable carbohydrates may be digested with endogenous enzymes in the first part of the gastrointestinal tract, or fermented by micro-organisms that colonise predominantly the last part of the gastrointestinal tract. Products derived from digestible carbohydrates are mainly monosaccharides. The digestion of starch and absorption of monosaccharides are primarily responsible for the fluctuations in the postprandial blood glucose concentrations that subsequently may modify tryptophan availability in the brain when protein intake is low (see section on Findings and mechanisms in different mammals: Tryptophan), and influence mood in at least humans (for a review, see Benton $\left.{ }^{117}\right)$. The indigestible carbohydrates are often referred to as dietary fibre, which contains non-starch polysaccharides, resistant starch and non-digestible oligosaccharides. The fermentation endproducts of dietary fibre are volatile fatty acids (VFA; acetic, propionic and butyric acid), lactate, alcohol and the gases methane, hydrogen and carbon dioxide ${ }^{118}$. Apart from the fermentability, other physical and chemical properties of dietary fibre include solubility, ability to bind water and affect viscosity, and possible interactions with the digestion and absorption of starch, protein and fat. In addition, the duration of satiety experienced by animals between meals may be affected by carbohydrates, which in turn may reduce the behavioural side effects of a high feed motivation.

\section{Findings and mechanisms in different mammals}

The effects of dietary carbohydrate sources (i.e. fibrous ingredients) on animal behaviour have been relatively well studied especially in pigs, where non-lactating sows were fed energy-restricted diets in order to prevent excessive lipid deposition and reduced reproduction performance. Commonly diets for sows are formulated to meet the daily nutrient requirements for maintenance and reproduction. However, the latter may not result in a sufficient level of 
satiety between meals and is believed to be an important reason for a persistent high feeding motivation throughout the day contributing to the development of stereotyped behaviour $^{119}$. In order to reduce stereotyped behaviour in sows, diets high in fibrous ingredients (sugarbeet pulp, oat hulls, soyabean hulls, wheat bran) can be fed ${ }^{120,121}$, resulting in an increased time of sows laying down ${ }^{122}$, increased resting time, less time spent on foraging and aggression $^{123}$ and reduced posture changes 8 and $10 \mathrm{~h}$ after feeding ${ }^{124}$. The latter authors compared sows fed a highand a low-fermentable carbohydrate diet (for further examples, see Meunier-Salaün et al. ${ }^{125}$ ). The relationship between dietary fibre content and stereotyped behaviour has also been documented in horses. A large survey among trainers of race horses in Sweden revealed a negative correlation between the amount of roughage provided and the incidence of stereotyped behaviour (cribbing or windsucking, weaving, box-walking) or wood-chewing in horses ${ }^{126}$. Wood-chewing may be related to a 'fibre deficiency' in the diet and represent attempts to increase dietary fibre intake $\mathrm{e}^{126-128}$. The effect of fibrous ingredients on behaviour is not generic for all fibre sources; for example, solvent-extracted coconut meal and soyabean hulls as a dietary fibre source do not appear to affect physical activity in pigs ${ }^{129}$, whereas sugarbeet pulp silage does $^{130}$. Since sows which are fed low amounts of feed were shown to be more active compared with sows fed large amounts of feed ${ }^{131}$ it has been suggested that hunger is most likely the cause of the increased physical activity ${ }^{132}$.

The variety in physical and chemical properties of different fibrous ingredients results in differences between these fibres in creating and maintaining satiety and preventing feelings of hunger. The biological mechanisms behind the satiating properties of dietary fibre are still not fully understood, but several dietary fibre characteristics seem to be important. First, fibres with a high water-binding capacity may increase the volume and weight of the gastric contents when liquids are available. The weight or volume may stimulate stretch receptors that can induce gastric signals of satiation ${ }^{114,133}$. Second, gastric emptying can be affected either directly by dietary fibres high in intragastric viscosity $^{134}$ or indirectly through the stimulation of the release of glucagon-like peptide-1 (GLP-1) (a potent inhibitor of gastric emptying ${ }^{135}$ ). Stimulation of GLP-1 production can be mediated through carbohydrate fermentation in the distal part of the gastrointestinal track ${ }^{136}$ or through the production of VFA (mainly acetate) which stimulates the release of peptide tyrosine tyrosine (PYY) ${ }^{137-139}$. The effects of GLP-1 and PYY in delaying gastric emptying are referred to as the 'ileal brake' mechanism which results in a moderate and stable flow of nutrients from the stomach into the small intestine ${ }^{114}$. A decrease in postprandial gastric-emptying rate will, consequently, prolong gastric distension and gastric signals of satiation $^{137-139}$. This mechanism was studied by Moran et $a l .^{141}$ in rhesus monkeys where intramuscular injections of PYY reduced gastric emptying and resulted in a decrease in food intake. In addition, there are indications that PYY in the brain reduces appetite in humans ${ }^{142}$, although this is still a subject for debate ${ }^{143}$. Third, fibrous dietary ingredients may increase small-intestinal transit time ${ }^{144}$, possibly also by stimulation of PYY which is found to suppress intestinal motility ${ }^{143}$. An increase in small-intestinal transit time: (i) prolongs contact between nutrients and intestinal receptors involved in maintaining satiety ${ }^{146,147}$ and postpones feelings of hunger ${ }^{12}$; (ii) results in the slowing down of starch digestion and subsequent absorption of glucose, thereby maintaining more stable postprandial glucose and insulin concentrations in the blood ${ }^{148}$. A transient decline in blood glucose level preceded meal initiation in rats ${ }^{149}$ and humans ${ }^{150,151}$ and caused a delay in the decrease in blood glucose concentrations. This may prolong satiety and postpone hunger and meal initiation (for a review, see Campfield \& Smith $^{152}$ ). Finally, fermentation of carbohydrates may yield VFA which leads to a higher level of satiety by (i) PYY-mediated reduction of gastric emptying rate $^{153}$ and (ii) becoming a source of energy (mainly acetate) at times when glucose supply from the small intestine is decreasing, which stimulates longer-term satiety ${ }^{18,133,154,155}$.

As suggested previously, hunger is most likely the cause for the observed behavioural effects seen in sows ${ }^{132}$. Hunger or appetite is correlated with the peripheral concentration of ghrelin $^{156}$, a twenty-eight amino acid peptide synthesised predominantly in the stomach ${ }^{157,158}$. For example, a rise in blood ghrelin concentration is associated with meal initiation in humans ${ }^{159}$. Supplementation of short-chain oligofructose (average degree of polymerization of 4.5) in a diet for 3 weeks decreased energy intake and lowered ghrelin concentrations in rats compared with rats fed the control diet without fructan supplementation. However, rats fed a diet supplemented with long-chain oligofructose (average degree of polymerization of 25.0) showed a decrease in energy intake but not in ghrelin concentrations compared to rats fed the control diet ${ }^{136}$. It is suggested that the lower blood ghrelin concentrations may contribute to a decrease in appetite during fasting ${ }^{160}$. Whether these results were accompanied with changes in behaviour (for example, food-seeking behaviour) requires further investigation. Fig. 2 shows the effects of dietary fibre on satiety.

\section{Findings in dogs}

'When we are considering how a dog is behaving, we really should be considering what is inside the stomach' (Mugford $^{66}$, p. 1046). Despite this statement, little additional research has been conducted on the association between canine behaviours and satiety or feeding motivation between meals. To the authors' knowledge, three studies have investigated the effects of dietary fibre on satiety and feeding motivation in dogs of which only one also studied canine behaviour and another measured ad libitum food intake of dogs fed diets varying in fibre source and content (Table 2). Butterwick \& Markwell ${ }^{161} \mathrm{fed}$ overweight dogs $(>115 \%$ ideal body weight) six different moist diets varying in type and amount of fibre on an energy-restricted basis $(45 \%$ restriction of calculated maintenance energy requirements; $\mathrm{ME}(\mathrm{kJ})=461 \times$ body weight $\left.(\mathrm{kg})^{0.75}\right)$. The four experimental high-fibre diets formulated to vary in soluble fibre (SF) and insoluble fibre (ISF), i.e. (g/kg DM) 40.8 SF and 13.6 ISF; $112.5 \mathrm{SF}$ and 


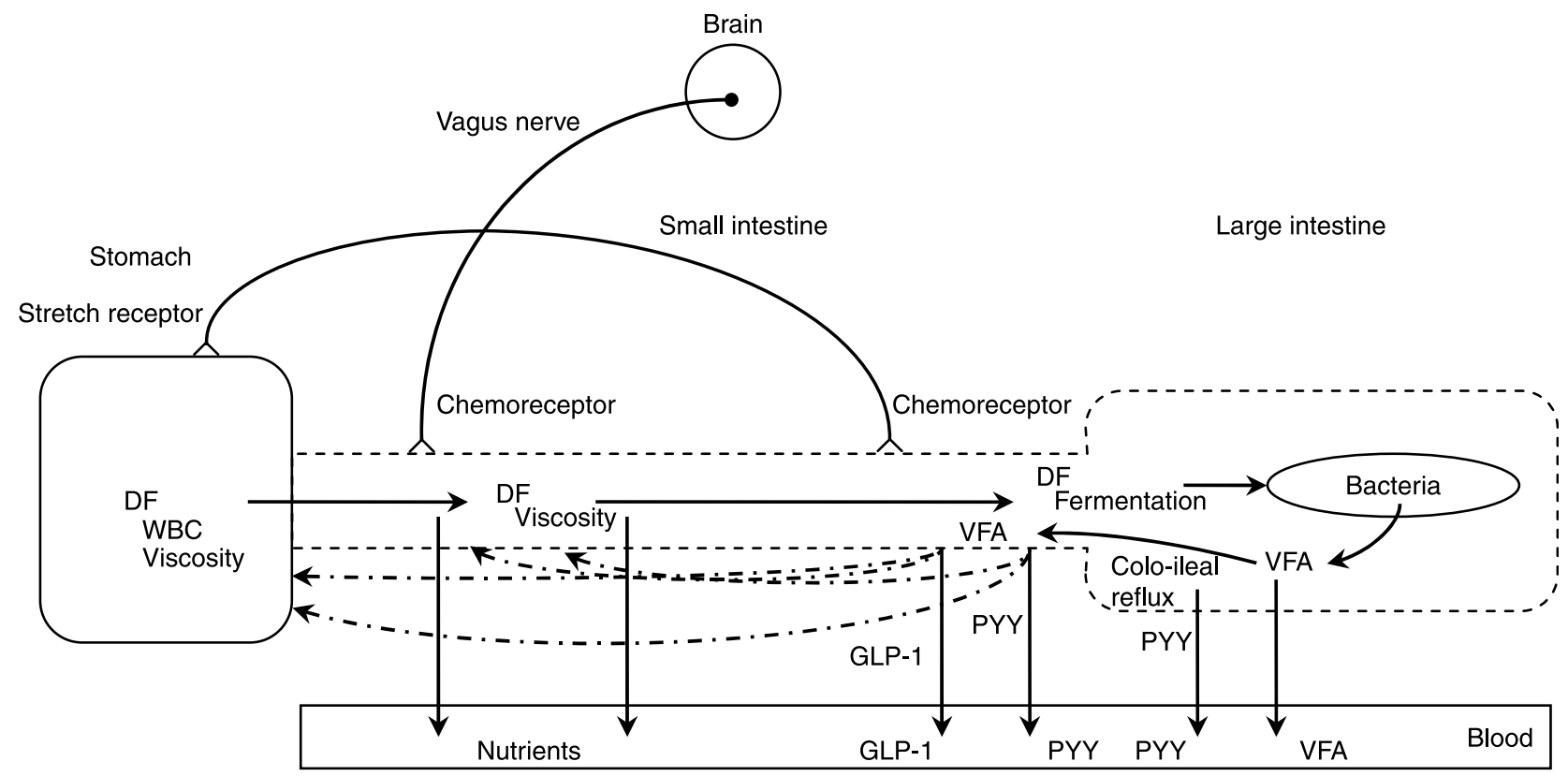

Fig. 2. Effects of dietary fibre (DF) on satiety. (- - ), Factors that may ultimately increase the residence time of digesta in the designated segments of the gastrointestinal tract; WBC, water-binding capacity; VFA, volatile fatty acids; GLP-1, glucagon-like peptide-1; PYY, peptide tyrosine tyrosine.

37.5 ISF; 35.7 SF and 202.4 ISF; 24.8 SF and 310.6 ISF, were compared with two dry control diets (36.5 SF and 14.6 ISF; $45 \cdot 5 \mathrm{SF}$ and $15 \cdot 2 \mathrm{ISF})$. The authors found no differences in time spent at behaviours related to feeding motivation (i.e. cumulative time spent at feeding bowl and number of visits to bowl $30 \mathrm{~min}$ after feeding, intake of a meal (canned diet) provided $3 \mathrm{~h}$ after introduction of the test diets) between dogs fed the different diets. In contrast, Jewell \& Toll ${ }^{162}$ did find effects of fibre content on the satiety of dogs. Dogs with ad libitum access to dry diets with a medium or high crude fibre content (135.5 and 223.4 g/kg DM) decreased total ME intake compared with dogs that had ad libitum access to low-crude fibre diets $(16 \cdot 3$ and $16 \cdot 4 \mathrm{~g} / \mathrm{kg} \mathrm{DM})$. When dogs were offered a subsequent meal, $30 \mathrm{~min}$ after the end of the last meal, energy and DM intake were lower in dogs fed the high-fibre diet compared with dogs consuming the low-fibre diet ${ }^{162}$. Similarly, Jackson et al. ${ }^{163}$ observed that a high-fibre content in dry diets reduced energy intakes in dogs. These authors fed dogs in the morning either a diet high in total dietary fibre (26.7 SF, 263.7 ISF g/kg as fed) or low in total dietary fibre (18.1 SF, $123.2 \mathrm{ISF} / \mathrm{kg}$ as fed) followed $6 \mathrm{~h}$ later by ad libitum access to a diet containing $23.2 \mathrm{SF}, 123.5$ ISF $/ \mathrm{kg}$ as fed. Average energy intake over the day was lower $(\mathrm{kJ} / \mathrm{kg}$ body weight $)$ in the dogs fed the high-fibre diet in the morning compared with the energy intake of the dogs fed the low-fibre diet in the morning (273 v. $332 \mathrm{~kJ}(65.3 v$. $79.4 \mathrm{kcal} / \mathrm{kg}$ body weight). The difference in average daily energy intake was the result of the energy intake in the morning since there were no significant differences observed in intake of the diet provided in the afternoon between the high-fibre $(181 \mathrm{~kJ}(43.2 \mathrm{kcal}) / \mathrm{kg}$ body weight $)$ and lowfibre $(197 \mathrm{~kJ}(47.2 \mathrm{kcal}) / \mathrm{kg}$ body weight) groups. These latter two studies showed that high levels of fibrous dietary ingredients in dogs can increase satiety and reduce energy intake. This, however, was not confirmed in a study by Butterwick \& Markwell ${ }^{161}$. The latter may be due to the energy restriction and the large differences in DM content of diets between studies. Energy restriction will result in an increased feeding motivation in dogs to a level that nullifies the possible effects of fibre on satiety ${ }^{163}$. DM content of the moist diets fed to dogs in the study of Butterwick \& Markwell $^{161}$ ranged between 132 and $168 \mathrm{~g} / \mathrm{kg}$ whereas Jewell \& Toll ${ }^{160}$ and Jackson et al. ${ }^{162}$ fed dry diets with a DM content between 908 and $923 \mathrm{~g} / \mathrm{kg}$. On an energy basis, intake of a diet with a high DM content or high energy density will result in lower weight of the digesta in the stomach compared with a diet with similar nutrient composition but lower DM content. A low dietary DM content will therefore have a higher weight of digesta in the stomach and will stimulate stretch receptors which affect satiety in $\operatorname{dogs}^{164}$. Finally, food intake in $\mathrm{g} D M / \mathrm{kg}$ body weight was found to be lower in dogs with ad libitum access to a diet with $15 \mathrm{~g}$ short chain fructo-oligosaccharides $/ \mathrm{kg}$ DM compared with dogs with ad libitum access to a diet with $60 \mathrm{~g}$ cellulose $/ \mathrm{kg} \mathrm{DM}^{165}$. The authors suggested that satiety between diets was altered because of the differences in fermentability of the fibre sources included in the diets. Unfortunately, no measurements were made in this study to elucidate possible mechanisms underlying their observed difference in food intake.

The mechanisms behind the observed effects of dietary fibre on inducing and maintaining satiety in humans and pigs (see previous section) have in part been also observed in dogs. Stimulation of stretch receptors through infusion of liquids or filling a balloon with water placed in the stomach reduced sham feeding in dogs, indicating that stimulation of stretch receptors induces satiety in $\operatorname{dogs}^{164}$. Gastric emptying was reduced in dogs as fibre (for example, psyllium, guar gum) content and viscosity of the meal increased ${ }^{166}$, which will prolong gastric distension 
Table 2. Effect of dietary fibre on food intake and canine behaviour

\begin{tabular}{|c|c|c|c|}
\hline Authors & Dogs and design & Dietary fibre content or source ${ }^{*}$ & Results \\
\hline $\begin{array}{l}\text { Jewell \& } \\
\text { Toll }^{160}\end{array}$ & $\begin{array}{l}\text { Study } 1 \text {, two groups of fifteen beagle } \\
\text { dogs were assigned to one of two } \\
\text { dry diets fed once per d at } \\
\text { maintenance level for } 14 \mathrm{~d} \\
\text { On day } 7 \text {, one of two diets was } \\
\text { provided } 75 \text { min after first meal. On } \\
\text { day } 14 \text {, the other diet was offered } \\
75 \text { min after first meal. After } 14 \mathrm{~d} \text {, } \\
\text { the experimental design was } \\
\text { repeated but each group of dogs } \\
\text { received the other of the two diets } \\
\text { Study } 2 \text {, identical as study } 1 \text { but } \\
\text { with different diets }\end{array}$ & $\begin{array}{l}\text { (1) } 16 \mathrm{~g} \mathrm{CF} / \mathrm{kg} \text { (study 1) } \\
\text { (2) } 136 \mathrm{~g} \mathrm{CF} / \mathrm{kg} \text { (study 1) } \\
\text { (3) } 16 \mathrm{~g} \mathrm{CF} / \mathrm{kg} \text { (study 2) } \\
\text { (4) } 223 \mathrm{~g} \mathrm{CF} / \mathrm{kg} \text { (study 2) }\end{array}$ & $\begin{array}{l}\text { (a) Energy intake of all dogs was } \\
\text { lower than energy on offer } \\
\text { (b) Dogs fed diets } 2 \text { and } 4 \text { had lower } \\
\text { daily energy intake than dogs fed } \\
\text { diets } 1 \text { and } 3 \text {, respectively } \\
\text { (c) Energy intake of the second meal } \\
75 \text { min after first meal was lower } \\
\text { when dogs were fed diets } 2 \text { and } 4 \\
\text { compared with dogs fed diets } 1 \\
\text { and } 3 \text {, respectively }\end{array}$ \\
\hline $\begin{array}{l}\text { Butterwick \& } \\
\text { Markwell }^{159}\end{array}$ & $\begin{array}{l}\text { Six obese terrier dogs }(>115 \% \text { of } \\
\text { ideal BW) were fed each of the six } \\
\text { wet diets }(6 \times 6 \text { Latin square) at } \\
45 \% \text { of maintenance level for } 12 \mathrm{~d} \text {. } \\
\text { Number of visits to the bowl and } \\
\text { cumulative time spent at the bowl } \\
\text { were observed for } 30 \text { min from the } \\
\text { start of the meal. On day } 7 \text { and } 10, \\
8 \text { and } 11 \text {, or } 9 \text { and } 12 \text {, dogs had ad } \\
\text { libitum access to a wet diet that was } \\
\text { provided } 180 \text { min after the first } \\
\text { meal and food intake was } \\
\text { measured }\end{array}$ & $\begin{array}{l}\text { (1) } 7 \mathrm{~g} \mathrm{CF} / \mathrm{kg} ; 41 \mathrm{~g} \mathrm{SF} / \mathrm{kg} ; 14 \mathrm{~g} \mathrm{ISF} / \mathrm{kg} \\
\text { (2) } 13 \mathrm{~g} \mathrm{CF} / \mathrm{kg} ; 113 \mathrm{~g} \mathrm{SF} / \mathrm{kg} ; 38 \mathrm{~g} \\
\mathrm{ISF} / \mathrm{kg} \\
\text { (3) } 143 \mathrm{~g} \mathrm{CF} / \mathrm{kg} ; 36 \mathrm{~g} \mathrm{SF} / \mathrm{kg} ; 202 \mathrm{~g} \\
\mathrm{ISF} / \mathrm{kg} \\
\text { (4) } 149 \mathrm{~g} \mathrm{CF} / \mathrm{kg} ; 25 \mathrm{~g} \mathrm{SF} / \mathrm{kg} ; 311 \mathrm{~g} \\
\mathrm{ISF} / \mathrm{kg} \\
\text { (5) } 15 \mathrm{~g} \mathrm{CF} / \mathrm{kg} ; 37 \mathrm{~g} \mathrm{SF} / \mathrm{kg} ; 15 \mathrm{~g} \\
\\
\mathrm{ISF} / \mathrm{kg} \\
\text { (6) } 8 \mathrm{~g} \mathrm{CF} / \mathrm{kg} ; 46 \mathrm{~g} \mathrm{SF} / \mathrm{kg} ; 15 \mathrm{~g} \mathrm{ISF} / \mathrm{kg}\end{array}$ & $\begin{array}{l}\text { (a) No differences between diets in } \\
\text { daily energy intake } \\
\text { (b) No differences between diets in } \\
\text { observed behaviours } \\
\text { (c) No differences between diets in } \\
\text { food intake of the second meal } \\
180 \text { min after first meal }\end{array}$ \\
\hline $\begin{array}{l}\text { Jackson } \\
\text { et al. }{ }^{161}\end{array}$ & $\begin{array}{l}\text { Two groups of fifteen miniature } \\
\text { schnauzers and toy poodles were } \\
\text { assigned to one of two dry diets fed } \\
\text { in the morning at } 50 \% \text { of daily } \\
\text { intake and had ad libitum access to } \\
\text { a control diet in the afternoon } \\
\text { (approximately } 6 \mathrm{~h} \text { later) for } 8 \mathrm{~d}\end{array}$ & $\begin{array}{l}\text { (1) } 95 \mathrm{~g} \mathrm{CF} / \mathrm{kg} ; 27 \mathrm{~g} \mathrm{SF} / \mathrm{kg} ; 264 \mathrm{~g} \\
\mathrm{ISF} / \mathrm{kg} \\
\text { (2) } 20 \mathrm{~g} \mathrm{CF} / \mathrm{kg} ; 18 \mathrm{~g} \mathrm{SF} / \mathrm{kg} ; 123 \mathrm{~g} \\
\text { ISF/kg } \\
\text { (3) } 21 \mathrm{~g} \mathrm{CF} / \mathrm{kg} ; 23 \mathrm{~g} \mathrm{SF} / \mathrm{kg} ; 124 \mathrm{~g} \\
\text { ISF/kg (control) }\end{array}$ & $\begin{array}{l}\text { (a) Dogs fed diet } 1 \text { had lower morning } \\
\text { and daily energy intake/kg BW } \\
\text { than dogs fed diet } 2 \\
\text { (b) There was no difference in food } \\
\text { intake of diet } 3 \text { in the afternoon } \\
\text { between dietary treatments }\end{array}$ \\
\hline $\begin{array}{l}\text { Howard } \\
\text { et al. }^{163}\end{array}$ & $\begin{array}{l}\text { Twenty-eight adult beagle dogs were } \\
\text { stratified by BW and assigned at } \\
\text { random to one of four dry diets with } \\
\text { ad libitum access for } 35 \mathrm{~d}\end{array}$ & $\begin{array}{l}\text { (1) } 60 \mathrm{~g} \text { cellulose } / \mathrm{kg} \\
\text { (2) } 15 \mathrm{~g} \mathrm{FOS} / \mathrm{kg} \\
\text { (3) } 60 \mathrm{~g} \text { beet pulp/kg } \\
\text { (4) } 60 \mathrm{~g} \text { beet pulp/kg; } 20 \mathrm{~g} \text { gum } \\
\text { talha } / \mathrm{kg} ; 15 \mathrm{~g} \text { FOS } / \mathrm{kg}\end{array}$ & $\begin{array}{l}\text { (a) No differences between diets in } \\
\text { DM intake per d } \\
\text { (b) Dogs fed diet } 2 \text { showed lower DM } \\
\text { intake/d per kg body weight } \\
\text { compared with dogs fed diet } 1\end{array}$ \\
\hline
\end{tabular}

CF, crude fibre; BW, body weight; SF, soluble fibre; ISF, insoluble fibre; FOS, fructo-oligosaccharides.

${ }^{*}$ Values are presented on a DM basis except for the data of Jackson et al. ${ }^{161}$, which are as-fed.

and gastric signals of satiation. In addition, a study of Bueno et al. ${ }^{144}$ in which dogs were fed different fibre sources (wheat bran, cellulose, guar gum), both gastric emptying and intestinal transit time were affected with the effect depending on the fibre source included.

A delay in gastric emptying and thus an increase in intestinal transit time by dietary fibre (alginate) results in more stable blood glucose concentrations as observed by Murray et al. ${ }^{167}$. In dogs fed a diet with a high level of fermentable fibres (sugarbeet pulp, gum arabic and fructo-oligosaccharides), intestinal GLP-1 concentrations were found to be increased compared with dogs fed a diet with low-fermentable fibre (cellulose) levels ${ }^{168}$. GLP-1 slows down gastric emptying ${ }^{135}$ and intestinal transit ${ }^{169}$, which may result in prolonged gastric fill and delayed nutrient digestion and absorption. In dogs, the 'ileal brake' mechanism may also result from stimulation of the release of PYY by fatty acids sufficient to delay gastric emptying in $\operatorname{dog} s^{171}$.

As reported above, fermentation of carbohydrates yields VFA ${ }^{118}$, which may lead to prolongation of satiety by becoming a source of energy (mainly acetate) at times when glucose supply from the small intestine is decreasing ${ }^{118,133,154,155}$. Although dogs have a relatively small and simple large intestine, dogs are capable of fermenting a significant quantity of dietary non-digestible carbohydrates ${ }^{172}$. Moreover, the faecal microflora of dogs were found to give similar in vitro organic matter disappearance results compared with the microflora from humans, pigs and horses ${ }^{173}$. The latter indicates that differences between these species in carbohydrate fermentation capacity are probably dependent on factors other than the microbial population. The extent of fermentation in the gastrointestinal tract in an animal largely depends on the time available for microbial fermentation ${ }^{173-175}$. In dogs, a transit time through the total gastrointestinal tract between 20 and $35 \mathrm{~h}$ is considered normal ${ }^{176}$. The large-intestinal transit of digesta can take up to $90 \%$ of the total gastrointestinal transit time $^{175,178}$, presenting a considerable time for large-intestinal microflora to ferment undigested substrates entering from the ileum. The VFA produced can be used by the hindgut bacteria for protein synthesis, resulting in an increase in microbial mass, or absorbed in the large intestine. The contribution of large-intestinal VFA absorption towards the total energy maintenance requirements of dogs has been reported to be approximately $2-7 \%^{179,180}$. However, the latter authors did 
not to provide information on the way these values were derived. In addition, the effect of production and absorption of acetate as an energy source for body tissues on postprandial satiety remains to be investigated. The work of Pouteau et al. ${ }^{181,182}$ on a method to evaluate acetate production and metabolism using stable isotopes may be the starting point for further exploration of the importance of carbohydrate fermentation in the gastrointestinal tract and satiety in dogs.

To our knowledge, there is no information available in the scientific literature regarding possible influences of dietary fibre on ghrelin concentrations and behaviour in dogs. However, when dogs are fed one scheduled meal per d, ghrelin concentrations increase before and decrease rapidly after the meal to remain relatively constant throughout the rest of the day ${ }^{183}$, which may indicate little potency of ghrelin concentrations to affect canine behaviour throughout the day.

Nowadays, dry extruded diets for dogs may contain $30 \%$ or more carbohydrates of which starch is the major component. Moreover, the non-digestible carbohydrate fraction in diets can also make up a considerable proportion $^{172}$. As mentioned previously, fibres differing in physical and chemical properties have diverse physiological responses in animals. Nutrient digestion as well as transit time through the gastrointestinal tract may be influenced by the amount and source of fibre included in canine diets. In the case of a reduction in nutrient digestibility when fibres are included, it is necessary to increase the concentration of some nutrients in order to ensure that the nutrient requirements of the animals are met $^{184}$. Future canine research on the behavioural effects of dietary fibre should account for the fact that different breeds may respond differently (in terms of satiety). Gastric emptying rate is inversely related to body weight in dogs of different sizes ${ }^{185}$. Moreover, large-breed dogs have a longer large-intestinal transit time and increased apparent total dietary fibre digestibility $^{186}$, which may increase the production and the use of VFA but may increase gastrointestinal discomfort as a result of enhanced fermentation activity.

The degree of satiety in animals such as pigs has been shown to affect behaviour, including aggressive and stereotyped behaviour. Although likely, it is up till now unknown whether canine behaviour can be affected by degree of satiety and further research is required. Assuming that behaviours in dogs are more favourable during times of satiety than during times of hunger as observed in pigs (for example, aggression), specific dietary fibres through their potential to prolong satiety may assist in preventing unwanted canine behaviours.

\section{Conclusions}

The present contribution provides an overview of current knowledge on the influence of dietary macronutrient composition on canine behaviour. It can be concluded that little research has been conducted in this field although research in other species indicates that there is potential to modify behaviour in dogs through nutrition. There is evidence that dietary composition can modulate animal and human behaviour through different mechanisms. Dietary protein may contain the precursors tryptophan and tyrosine for the respective neurotransmitters serotonin and catecholamines. Since bioavailability of both tryptophan and tyrosine in the brain are dependent on the dietary protein content and amino acid composition, dietary composition may have an impact on the behaviour and wellbeing of dogs under specific circumstances (for example, stress). However, before application and extrapolation of the evidence found in mostly rodent laboratory studies into commercial canine diets is undertaken, research is required to identify the optimal and safe dietary inclusion level in combination with behavioural tests to study the magnitude of effects on (problem) canine behaviour. The $n-3$ PUFA have an important role in the development of the brain, and the supply of essential fatty acids such as DHA could affect aspects of the dopaminergic and serotonergic system and, consequently, cognitive performance and behaviour as observed in rodents. Most canine studies and dietary $n-3$ PUFA have been mainly focused on the effect of maternal intake of different dietary $n-3$ PUFA during gestation and lactation on $n$-3 PUFA in the milk and/or $n$-3 PUFA intake on retinal function of puppies. It would be of interest to examine the DHA required for optimal neurological development and whether this leads to alterations in cognitive abilities or behaviour later in life of dogs. In the literature, studies have been reported which show that, depending on the physical and chemical properties, certain dietary fibres induce satiation or prolongation of satiety after a meal. However, there have been no studies conducted in which the effect of dietary fibre on physiological satiety parameters, behaviour (for example, activity) and/or feeding motivation were studied in dogs. If dietary fibre has shortterm effects that result in prolongation of satiety and a reduction of hunger between meals, it may help to prevent unwanted canine behaviours and also promote long-term weight control.

\section{References}

1. Vilà C, Savoleinen $\mathrm{P}$, Maldonado JE, Amorim IR, Rice JE, Honeycutt RL, Crandall KA, Lundeberg J \& Wayne RK (1997) Multiple and ancient origins of the domestic dog. Science 276, 1687-1689.

2. Savolainen P, Zhang Y-P, Luo J, Lundeberg J \& Leitner T (2002) Genetic evidence for an East Asian origin of domestic dogs. Science 298, 1610-1613.

3. Hart BL (1995) Analysing breed and gender differences in behaviour. In The Domestic Dog: Its Evolution, Behaviour and Interactions with People, pp. 65-77 [J Serpell, editor]. Cambridge, UK: Cambridge University Press.

4. Marston LC \& Bennett PC (2003) Reforging the bond towards successful canine adoption. Appl Anim Behav Sci 83, 227-245.

5. Salman MD, Hutchison J, Ruch-Gallie R, Kogan L, New JC Jr, Kass PH \& Scarlett JM (2000) Behavioral reasons for relinquishment of dogs and cats to 12 shelters. J Appl Anim Welf Sci 3, 93-106.

6. Patronek GJ, Glickman LT, Beck AM, McCabe GP \& Ecker C (1996) Risk factors for relinquishment of dogs to an animal shelter. J Am Vet Med Assoc 209, 572-581.

7. Houpt KA, Honig SU \& Reisner IR (1996) Breaking the human-companion animal bond. J Am Vet Med Assoc 208, 1653-1659. 
8. Carter CN (1990) Pet population control: another decade without solutions? J Am Vet Med Assoc 197, 192-195.

9. Rowan A (1992) Shelters and pet overpopulation: a statistical black hole. Anthrozoös 5, 140-143.

10. Dodman NH \& Shuster L (1998) Preface. In Psychopharmacology of Animal Behavior Disorders, pp. vii-xi [NH Dodman and L Shuster, editors]. Malden, MA: Blackwell Science.

11. Schoenthaler SJ \& Bier ID (2000) The effect of vitaminmineral supplementation on juvenile delinquency among American schoolchildren: a randomized, double-blind placebo-controlled trial. J Altern Complement Med 6, 7-17.

12. Gesch CB, Hammond SM, Hampson SE, Eves A \& Crowder MJ (2002) Influence of supplementary vitamins, minerals and essential fatty acids on the antisocial behaviour of young adult prisoners. Randomised, placebocontrolled trial. Br J Psychiatry 181, 22-28.

13. Studzinski CM, Araujo JA \& Milgram NW (2005) The canine model of human cognitive aging and dementia: pharmacological validity of the model for assessment of human cognitive-enhancing drugs. Prog Neuropsychopharmacol Biol Psychiatry 29, 489-498.

14. Roudebush P, Zicker SC, Cotman CW, Milgram NW, Muggenburg BA \& Head E (2005) Nutritional management of brain aging in dogs. J Am Vet Med Assoc 227, 722-728.

15. Zicker SC (2005) Cognitive and behavioral assessment in dogs and pet food market applications. Prog Neuropsychopharmacol Biol Psychiatry 29, 455-459.

16. Massey KA, Blakeslee CH \& Pitkow HS (1998) A review of physiological and metabolic effects of essential amino acids. Amino Acids 14, 271-300.

17. Young SN (1996) Behavioral effects of dietary neurotransmitter precursors: basic and clinical aspects. Neurosci Biobehav Rev 20, 313-323.

18. Gibbons JL, Barr GA, Bridger WH \& Leibowitz SF (1979) Manipulations of dietary tryptophan: effects on mouse killing and brain serotonin in the rat. Brain Res 169, $139-153$.

19. Kantak KM, Hegstrand LR, Whitman J \& Eichelman B (1980) Effects of dietary supplements and a tryptophan-free diet on aggressive behavior in rats. Pharmacol Biochem Behav 12, 173-179.

20. Chamberlain B, Ervin FR, Pihl RO \& Young SN (1987) The effect of raising or lowering tryptophan levels on aggression in vervet monkeys. Pharmacol Biochem Behav 28, $503-510$.

21. Rouvinen K, Archbold S, Laffin S \& Harri M (1999) Longterm effects of tryptophan on behavioural response and growing-furring performance in silver fox (Vulpes vulpes). Appl Anim Behav Sci 63, 65-77.

22. Weld KP, Mench JA, Woodward RA, Bolesta MS, Suomi SJ \& Higley JD (1998) Effect of tryptophan treatment on selfbiting and central nervous system serotonin metabolism in rhesus monkeys (Macaca mulatta). Neuropsychopharmacology 19, 314-321.

23. Lasley SM \& Thurmond JB (1985) Interaction of dietary tryptophan and social isolation on territorial aggression, motor activity, and neurochemistry in mice. Psychopharmacology 87, 313-321.

24. Koopmans SJ, Ruis M, Dekker R, van Diepen H, Korte M \& Mroz Z (2005) Surplus dietary tryptophan reduces plasma cortisol and noradrenaline concentrations and enhances recovery after social stress in pigs. Physiol Behav 85, 469-478.

25. Markus CR, Olivier B, Panhuysen GE, Van Der Gugten J, Alles MS, Tuiten A, Westenberg HG, Fekkes D, Koppeschaar HF \& de Haan EE (2000) The bovine protein $\alpha$-lactalbumin increases the plasma ratio of tryptophan to the other large neutral amino acids, and in vulnerable subjects raises brain serotonin activity, reduces cortisol concentration, and improves mood under stress. Am J Clin Nutr 71, 1536-1544.

26. Morgan WW, Rudeen PK \& Pfeil KA (1975) Effect of immobilization stress on serotonin content and turnover in regions of the rat brain. Life Sci 17, 143-150.

27. Milakofsky L, Hare TA, Miller JM \& Vogel WH (1985) Rat plasma levels of amino acids and related compounds during stress. Life Sci 36, 753-761.

28. Okuda C, Saito A, Miyazaki M \& Kuriyama K (1986) Alteration of the turnover of dopamine and 5-hydroxytryptamine in rat brain associated with hypothermia. Pharmacol Biochem Behav 24, 79-83.

29. Dunn AJ (1988) Changes in plasma and brain tryptophan and brain serotonin and 5-hydroxyindoleacetic acid after footshock stress. Life Sci 42, 1847-1853.

30. Branchey L, Branchey M, Shaw S \& Lieber CS (1984) Depression, suicide, and aggression in alcoholics and their relationship to plasma amino acids. Psychiatry Res 12, 219-226.

31. Sainio E-L, Pulkki K \& Young SN (1996) L-Tryptophan: biochemical, nutritional and pharmacological aspects. Amino Acids 10, 21-47.

32. Rodwell VW (1979) Protein \& amino acid metabolism: conversion of amino acids to specialized products. In Review of Physiological Chemistry, pp. 430-439 [HA Harper, VW Rodwell and PA Mayes, editors]. Los Altos, CA: Lange Medical Publications.

33. Carlsson A \& Lindqvist M (1978) Dependence of 5-HT and catecholamine synthesis on concentrations of precursor amino-acids in rat brain. Naunyn-Schmiedebergs Arch Pharmacol 303, 157-164.

34. Fernstrom JD \& Wurtman RJ (1972) Brain serotonin content: physiological regulation by plasma neutral amino acids. Science 178, 149-152.

35. Barnes NM \& Sharp T (1999) A review of central 5-HT receptors and their function. Neuropharmacology 38, $1083-1152$

36. Hoyer D, Hannon JP \& Martin GR (2002) Molecular, pharmacological and functional diversity of 5-HT receptors. Pharmacol Biochem Behav 71, 533-554.

37. Lucki I (1998) The spectrum of behaviors influenced by serotonin. Biol Psychiatry 44, 151-162.

38. Bagshaw CS, Ralston SL \& Fisher H (1994) Behavioral and physiological effect of orally administered tryptophan on horses subjected to acute isolation stress. Appl Anim Behav Sci 40, 1-12.

39. Henry Y, Seve B, Mounier A \& Ganier P (1996) Growth performance and brain neurotransmitters in pigs as affected by tryptophan, protein, and sex. J Anim Sci 74, 2700-2710.

40. Raleigh MJ, Brammer GL, McGuire MT \& Yuwiler A (1985) Dominant social status facilitates the behavioral effects of serotonergic agonists. Brain Res 348, 274-282.

41. Mench JA \& Shea-Moore MM (1995) Moods, minds and molecules: the neurochemistry of social behavior. Appl Anim Behav Sci 44, 99-118.

42. Peremans K, Audenaert K, Blanckaert P, et al. (2002) Effects of aging on brain perfusion and serotonin-2A receptor binding in the normal canine brain measured with single photon emission tomography. Prog Neuropsychopharmacol Biol Psychiatry 26, 1393-1404.

43. Chaouloff F, Laude D, Guezennec Y \& Elghozi JL (1986) Motor activity increases tryptophan, 5-hydroxyindoleacetic acid, and homovanillic acid in ventricular cerebrospinal fluid of the conscious rat. J Neurochem 46, 1313-1316. 
44. Trulson ME \& Jacobs BL (1979) Raphe unit activity in freely moving cats: correlation with level of behavioral arousal. Brain Res 163, 135-150.

45. Spring B, Chiodo J \& Bowen DJ (1987) Carbohydrates, tryptophan, and behavior: a methodological review. Psychol Bull 102, 234-256.

46. Yuwiler A, Oldendorf WH, Geller E \& Braun L (1977) Effect of albumin binding and amino acid competition on tryptophan uptake into brain. J Neurochem 28, 1015-1023.

47. Leathwood PD (1987) Tryptophan availability and serotonin synthesis. Proc Nutr Soc 46, 143-156.

48. Chaouloff F (1993) Physiopharmacological interactions between stress hormones and central serotonergic systems. Brain Res Rev 18, 1-32.

49. Fuller RW \& Roush BW (1973) Binding of tryptophan to plasma proteins in several species. Comp Biochem Physiol B 46, 273-276.

50. Pardridge WM (1998) Blood-brain barrier carrier-mediated transport and brain metabolism of amino acids. Neurochem Res 23, 635-644.

51. McMenamy RH (1965) Binding of indole analogues to human serum albumin. Effects of fatty acids. J Biol Chem 240, 4235-4243.

52. Badawy AA (1977) The functions and regulation of tryptophan pyrrolase. Life Sci 21, 755-768.

53. Pozefsky T, Felig P, Tobin JD, Soeldner JS \& Cahill GF Jr (1969) Amino acid balance across tissues of the forearm in postabsorptive man. Effects of insulin at two dose levels. J Clin Invest 48, 2273-2282.

54. Fernstrom JD \& Wurtman RJ (1972) Elevation of plasma tryptophan by insulin in rat. Metabolism 21, 337-342.

55. Benton D \& Donohoe RT (1999) The effects of nutrients on mood. Public Health Nutr 2, 403-409.

56. Rauch TM \& Lieberman HR (1990) Tyrosine pretreatment reverses hypothermia-induced behavioral depression. Brain Res Bull 24, 147-150.

57. Lehnert H, Reinstein DK, Strowbridge BW \& Wurtman RJ (1984) Neurochemical and behavioral consequences of acute, uncontrollable stress: effects of dietary tyrosine. Brain Res 303, 215-223.

58. Reinstein DK, Lehnert H, Scott NA \& Wurtman RJ (1984) Tyrosine prevents behavioral and neurochemical correlates of an acute stress in rats. Life Sci 34, 2225-2231.

59. Reinstein DK, Lehnert H \& Wurtman RJ (1985) Dietary tyrosine suppresses the rise in plasma corticosterone following acute stress in rats. Life Sci 37, 2157-2163.

60. Lieberman HR (1994) Tyrosine and stress: human and animal studies. In Food Components to Enhance Performance: an Evaluation of Potential Performance-Enhancing Food Components for Operational Rations, pp. 277-299 [BM Marriott, editor]. Washington, DC: National Academy Press.

61. Fernstrom JD \& Fernstrom MH (1994) Dietary effects on tyrosine availability and catecholamine synthesis in the central nervous system: possible relevance to the control of protein intake. Proc Nutr Soc 53, 419-429.

62. Wurtman RJ, Hefti F \& Melamed E (1980) Precursor control of neurotransmitter synthesis. Pharmacol Rev 32, 315-335.

63. Brady K, Brown JW \& Thurmond JB (1980) Behavioral and neurochemical effects of dietary tyrosine in young and aged mice following cold-swim stress. Pharmacol Biochem Behav 12, 667-674.

64. Yeghiayan SK, Luo S, Shukitt-Hale B \& Lieberman HR (2001) Tyrosine improves behavioral and neurochemical deficits caused by cold exposure. Physiol Behav 72, 311-316.
65. DeNapoli JS, Dodman NH, Shuster L, Rand WM \& Gross KL (2000) Effect of dietary protein content and tryptophan supplementation on dominance aggression, territorial aggression, and hyperactivity in dogs. $J$ Am Vet Med Assoc 217, 504-508.

66. Mugford RA (1987) The influence of nutrition on canine behaviour. J Small Anim Pract 28, 1046-1055.

67. Dodman NH, Reisner IR, Shuster L, Rand WM, Luescher UA, Robinson I \& Houpt KA (1996) Effect of dietary protein content on behavior in dogs. J Am Vet Med Assoc 208, 376-379.

68. National Research Council (2006) Nutrient Requirements of Dogs and Cats. Washington, DC: National Academy Press.

69. Association of American Feed Control Officials (2004) Official Publication of the Association of American Feed Control Officials. Atlanta, GA: AAFCO.

70. Lieberman HR (1999) Amino acid and protein requirements: cognitive performance, stress and brain function. In The Role of Protein and Amino Acids in Sustaining and Enhancing Performance, pp. 289-307 [Committee of Military Nutrition Research and Institute of Medicine, editor]. Washington, DC: National Academy Press.

71. Reeds PJ (2000) Dispensable and indispensable amino acids for humans. J Nutr 130, S1835-S1840.

72. Carrié I, Clement M, de Javel D, Francès H \& Bourre JM (2000) Specific phospholipid fatty acid composition of brain regions in mice. Effects of $n-3$ polyunsaturated fatty acid deficiency and phospholipid supplementation. J Lipid Res 41, 465-472.

73. Lauritzen L, Hansen HS, Jørgensen MH \& Michaelsen KF (2001) The essentiality of long chain $n$ - 3 fatty acids in relation to development and function of the brain and retina. Prog Lipid Res 40, 1-94.

74. Wainwright PE (1992) Do essential fatty acids play a role in brain and behavioral development? Neurosci Biobehav Rev 16, 193-205.

75. McCann JC \& Ames BN (2005) Is docosahexaenoic acid, an n-3 long-chain polyunsaturated fatty acid, required for development of normal brain function? An overview of evidence from cognitive and behavioral tests in humans and animals. Am J Clin Nutr 82, 281-295.

76. Bourre JM, Francois M, Youyou A, Dumont O, Piciotti M, Pascal G \& Durand G (1989) The effects of dietary $\alpha$ linolenic acid on the composition of nerve membranes, enzymatic activity, amplitude of electrophysiological parameters, resistance to poisons and performance of learning tasks in rats. $J$ Nutr 119, 1880-1892.

77. Moriguchi T, Greiner RS \& Salem N Jr (2000) Behavioral deficits associated with dietary induction of decreased brain docosahexaenoic acid concentration. J Neurochem $\mathbf{7 5}$, 2563-2573.

78. Lim S \& Suzuki H (2001) Changes in maze behavior of mice occur after sufficient accumulation of docosahexaenoic acid in brain. $J$ Nutr 131, 319-324.

79. Wainwright PE, Xing HC, Ward GR, Huang YS, Bobik E, Auestad N \& Montalto M (1999) Water maze performance is unaffected in artificially reared rats fed diets supplemented with arachidonic acid and docosahexaenoic acid. J Nutr 129, 1079-1089.

80. Wainwright PE, Xing HC, Mutsaers L, McCutcheon D \& Kyle D (1997) Arachidonic acid offsets the effects on mouse brain and behavior of a diet with a low $(n-6)(n-3)$ ratio and very high levels of docosahexaenoic acid. J Nutr 127, 184-193.

81. DeMar JC Jr, Ma K, Bell JM, Igarashi M, Greenstein D \& Rapoport SI (2006) One generation of $n-3$ polyunsaturated 
fatty acid deprivation increases depression and aggression test scores in rats. J Lipid Res 47, 172-180.

82. Takeuchi T, Iwanaga M \& Harada E (2003) Possible regulatory mechanism of DHA-induced anti-stress reaction in rats. Brain Res 964, 136-143.

83. Carrié I, Clement M, de Javel D, Francès H \& Bourre JM (2000) Phospholipid supplementation reverses behavioral and biochemical alterations induced by $n-3$ polyunsaturated fatty acid deficiency in mice. J Lipid Res 41, 473-480.

84. Francès H, Coudereau JP, Sandouk P, Clément M, Monier C \& Bourre JM (1996) Influence of a dietary $\alpha$-linolenic acid deficiency on learning in the Morris water maze and on the effects of morphine. Eur J Pharmacol 298, 217-225.

85. Chalon S, Delion-Vancassel S, Belzung C, Guilloteau D, Leguisquet AM, Besnard JC \& Durand G (1998) Dietary fish oil affects monoaminergic neurotransmission and behavior in rats. J Nutr 128, 2512-2519.

86. McEntee WJ \& Crook TH (1991) Serotonin, memory, and the aging brain. Psychopharmacology 103, 143-149.

87. Graeff FG, Guimaraes FS, De Andrade TG \& Deakin JF (1996) Role of 5-HT in stress, anxiety, and depression. Pharmacol Biochem Behav 54, 129-141.

88. Meneses A (1998) Physiological, pathophysiological and therapeutic roles of 5-HT systems in learning and memory. Rev Neurosci 9, 275-289.

89. Missale C, Nash SR, Robinson SW, Jaber M \& Caron MG (1998) Dopamine receptors: from structure to function. Physiol Rev 78, 189-225.

90. Schultz W (1998) Predictive reward signal of dopamine neurons. J Neurophysiol 80, 1-27.

91. Delion S, Chalon S, Herault J, Guilloteau D, Besnard JC \& Durand G (1994) Chronic dietary $\alpha$-linolenic acid deficiency alters dopaminergic and serotoninergic neurotransmission in rats. $J$ Nutr 124, 2466-2476.

92. Delion S, Chalon S, Guilloteau D, Besnard JC \& Durand G (1996) $\alpha$-Linolenic acid dietary deficiency alters age-related changes of dopaminergic and serotoninergic neurotransmission in the rat frontal cortex. $J$ Neurochem 66, $1582-1591$.

93. Zimmer L, Delion-Vancassel S, Durand G, Guilloteau D, Bodard S, Besnard JC \& Chalon S (2000) Modification of dopamine neurotransmission in the nucleus accumbens of rats deficient in $n-3$ polyunsaturated fatty acids. J Lipid Res 41, 32-40.

94. Zimmer L, Vancassel S, Cantagrel S, Breton P, Delamanche S, Guilloteau D, Durand G \& Chalon S (2002) The dopamine mesocorticolimbic pathway is affected by deficiency in $n$-3 polyunsaturated fatty acids. Am J Clin Nutr 75, 662-667.

95. Zimmer L, Delpal S, Guilloteau D, Aioun J, Durand G \& Chalon S (2000) Chronic $n-3$ polyunsaturated fatty acid deficiency alters dopamine vesicle density in the rat frontal cortex. Neurosci Lett 284, 25-28.

96. de la Presa Owens S \& Innis SM (1999) Docosahexaenoic and arachidonic acid prevent a decrease in dopaminergic and serotoninergic neurotransmitters in frontal cortex caused by a linoleic and $\alpha$-linolenic acid deficient diet in formula-fed piglets. $J$ Nutr 129, 2088-2093.

97. Kodas E, Galineau L, Bodard S, Vancassel S, Guilloteau D, Besnard JC \& Chalon S (2004) Serotoninergic neurotransmission is affected by $n-3$ polyunsaturated fatty acids in the rat. J Neurochem $\mathbf{8 9}, 695-702$.

98. Delion S, Chalon S, Guilloteau D, Lejeune B, Besnard JC \& Durand G (1997) Age-related changes in phospholipid fatty acid composition and monoaminergic neurotransmission in the hippocampus of rats fed a balanced or an n-3 polyunsaturated fatty acid-deficient diet. J Lipid Res $\mathbf{3 8}$, 680-689.

99. Kitajka K, Sinclair AJ, Weisinger RS, Weisinger HS, Mathai M, Jayasooriya AP, Halver JE \& Puskás LG (2004) Effects of dietary omega-3 polyunsaturated fatty acids on brain gene expression. Proc Natl Acad Sci USA 101, 10931-10936.

100. Bourre JM, Bonneil M, Dumont O, Piciotti M, Nalbone G \& Lafont H (1988) High dietary fish oil alters the brain polyunsaturated fatty acid composition. Biochim Biophys Acta 960, 458-461.

101. Bourre JM, Bonneil M, Dumont O, Piciotti M, Calaf R, Portugal H, Nalbone G \& Lafont H (1990) Effect of increasing amounts of dietary fish oil on brain and liver fatty composition. Biochim Biophys Acta 1043, 149-152.

102. Yehuda S, Rabinovitz S \& Mostofsky DI (1999) Essential fatty acids are mediators of brain biochemistry and cognitive functions. J Neurosci Res 56, 565-570.

103. Heinemann KM, Waldron MK, Bigley KE, Lees GE \& Bauer JE (2005) Long-chain (n-3) polyunsaturated fatty acids are more efficient than (-linolenic acid in improving electroretinogram responses of puppies exposed during gestation, lactation, and weaning. J Nutr 135, 1960-1966.

104. Bauer JE, Heinemann KM, Lees GE \& Waldron MK (2006) Retinal functions of young dogs are improved and maternal plasma phospholipids are altered with diets containing longchain $n$-3 polyunsaturated fatty acids during gestation, lactation, and after weaning. J Nutr 136, S1991-S1994.

105. Bauer JE, Heinemann KM, Bigley KE, Lees GE \& Waldron MK (2004) Maternal diet $\alpha$-linolenic acid during gestation and lactation does not increase docosahexaenoic acid in canine milk. $J$ Nutr 134, S2035-S2038.

106. Bauer JE, Heinemann KM, Lees GE \& Waldron MK (2006) Docosahexaenoic acid accumulates in plasma of canine puppies raised on $\alpha$-linolenic acid-rich milk during suckling but not when fed $\alpha$-linolenic acid-rich diets after weaning. J Nutr 136, S2087-S2089.

107. Biagi G, Mordenti AL, Cocchi M \& Mordenti A (2004) The role of dietary omega- 3 and omega- 6 essential fatty acids in the nutrition of dogs and cats: a review. Prog Nutr 6, 97-107.

108. Delton-Vandenbroucke I, Maude MB, Chen H, Aguirre GD, Acland GM \& Anderson RE (1998) Effect of diet on the fatty acid and molecular species composition of dog retina phospholipids. Lipids 33, 1187-1193.

109. Ahlstrøm Ø, Krogdahl A, Vhile SG \& Skrede A (2004) Fatty acid composition in commercial dog foods. J Nutr 134, S2145-S2147.

110. Blundell J (1991) Pharmacological approaches to appetite suppression. Trends Pharmacol Sci 12, 147-157.

111. Rowland NE, Morien A \& Li BH (1996) The physiology and brain mechanisms of feeding. Nutrition 12, 626-639.

112. Read NW (1992) Role of gastrointestinal factors in hunger and satiety in man. Proc Nutr Soc 51, 7-11.

113. Bray GA (2000) Afferent signals regulating food intake. Proc Nutr Soc 59, 373-384.

114. de Graaf C, Blom WA, Smeets PA, Stafleu A \& Hendriks HF (2004) Biomarkers of satiation and satiety. Am J Clin Nutr 79, 946-961.

115. Strader AD \& Woods SC (2005) Gastrointestinal hormones and food intake. Gastroenterology 128, 175-191.

116. Cummings JH, Roberfroid MB, Andersson H, Barth C, Ferro-Luzzi A, Ghoos Y, Gibney M, Hermansen K, James WP, Korver O, Lairon D, Pascal G \& Voragen AG (1997) A new look at dietary carbohydrate: chemistry, physiology and health. Eur J Clin Nutr 51, 417-423. 
117. Benton D (2002) Carbohydrate ingestion, blood glucose and mood. Neurosci Biobehav Rev 26, 293-308.

118. Bergman EN (1990) Energy contributions of volatile fatty acids from the gastrointestinal tract in various species. Physiol Rev 70, 567-590.

119. Lawrence AB \& Terlouw EM (1993) A review of behavioral factors involved in the development and continued performance of stereotypic behaviors in pigs. J Anim Sci 71, 2815-2825.

120. Ramonet Y, Meunier-Salaün MC \& Dourmad JY (1999) High-fiber diets in pregnant sows: digestive utilization and effects on the behavior of the animals. J Anim Sci 77, 591-599.

121. Bergeron R, Bolduc J, Ramonet Y, Meunier-Salaün MC \& Robert S (2000) Feeding motivation and stereotypies in pregnant sows fed increasing levels of fibre and/or food. Appl Anim Behav Sci 70, 27-40.

122. Robert S, Matte JJ, Farmer C, Girard CL \& Martineau GP (1993) High-fibre diets for sows: effects on stereotypies and adjunctive drinking. Appl Anim Behav Sci 37, 297-309.

123. Danielsen V \& Verstergaard E-M (2001) Dietary fibre for pregnant sows: effect on performance and behaviour. Anim Feed Sci Technol 90, 71-80.

124. de Leeuw JA, Jongbloed AW \& Verstegen MWA (2004) Dietary fiber stabilizes blood glucose and insulin levels and reduces physical activity in sows (Sus scrofa). J Nutr 134, $1481-1486$.

125. Meunier-Salaün MC, Edwards SA \& Robert S (2001) Effect of dietary fibre on the behaviour and health of the restricted fed sow. Anim Feed Sci Technol 90, 53-69.

126. Redbo I, Redbo-Torstensson P, Ödberg FO, Hedendahl A \& Holm J (1998) Factors affecting behavioural disturbances in race-horses. Anim Sci 66, 475-481.

127. Willard JG, Willard JC, Wolfram SA \& Baker JP (1977) Effect of diet on cecal $\mathrm{pH}$ and feeding behaviour of horses. J Anim Sci 45, 87-93.

128. Krzak WE, Gonyou HW \& Lawrence LM (1991) Wood chewing by stabled horses: diurnal pattern and effects of exercise. J Anim Sci 69, 1053-1058.

129. Rijnen MM, Verstegen MWA, Heetkamp MJ \& Schrama JW (2003) Effects of two different dietary fermentable carbohydrates on activity and heat production in grouphoused growing pigs. J Anim Sci 81, 1210-1219.

130. Rijnen MM, Verstegen MW, Heetkamp MJ, Haaksma J \& Schrama JW (2003) Effects of dietary fermentable carbohydrates on behavior and heat production in grouphoused sows. J Anim Sci 81, 182-190.

131. Spoolder HAM, Burbidge JA, Edwards SA, Simmins PH \& Lawrence AB (1995) Provision of straw as a foraging substrate reduces the development of excessive chain and bar manipulation in food restricted sows. Appl Anim Behav Sci 43, 249-262.

132. de Leeuw JA, Zonderland JJ, Altena H, Spoolder HAM, Jongbloed AW \& Verstegen MWA (2005) Effects of levels and sources of dietary fermentable non-starch polysaccharides on blood glucose stability and behaviour of grouphoused pregnant gilts. Appl Anim Behav Sci 94, 15-29.

133. van Leeuwen $\mathrm{P}$, van Gelder $\mathrm{AH}$, de Leeuw JA \& van der Klis JD (2006) An animal model to study digesta passage in different compartments of the gastro-intestinal tract (GIT) as affected by dietary composition. Curr Nutr Food Sci $\mathbf{2}$, 97-105.

134. Guerin S, Ramonet Y, LeCloarec J, Meunier-Salaün MC, Bourguet P \& Malbert CH (2001) Changes in intragastric meal distribution are better predictors of gastric emptying rate in conscious pigs than are meal viscosity or dietary fibre concentration. Br J Nutr 85, 343-350.
135. Anvari M, Paterson CA, Daniel EE \& McDonald TJ (1998) Effects of GLP-1 on gastric emptying, antropyloric motility, and transpyloric flow in response to a nonnutrient liquid. Dig Dis Sci 43, 1133-1140.

136. Cani PD, Dewever C \& Delzenne NM (2004) Inulin-type fructans modulate gastrointestinal peptides involved in appetite regulation (glucagon-like peptide-1 and ghrelin) in rats. Br J Nutr 92, 521-526.

137. Brown AJ, Goldsworthy SM, Barnes AA, Eilert MM, Tcheang L, Daniels D, Muir AI, Wigglesworth MJ, Kinghorn I, Fraser NJ, Pike NB, Strum JC, Steplewski KW, Murdock PR, Holder JC, Marshall PH, Szekeres PG, Wilson S, Ignar DM, Foord SM, Wise A \& Dowell SJ (2003) The Orphan G protein-coupled receptors GPR41 and GPR43 are activated by propionate and other short chain carboxylic acids. The Journal of Biological Chemistry 278, 11312-11319.

138. Le Poul E, Loison C, Struyf S, Springael JY, Lannoy V, Decobecq ME, Brezillon S, Dupriez V, Vassart G, Van Damme J, Parmentier M \& Detheux M (2003) Functional characterization of human receptors for short chain fatty acids and their role in polymorphonuclear cell activation. The Journal of Biological Chemistry 278, 25481-25489.

139. Karaki S, Mitsui R, Hayashi H, Kato I, Sugiya H, Iwanaga T, Furness JB \& Kuwahara A (2006) Short-chain fatty acid receptor, GPR43, is expressed by endoroendocrine cells and mucosal mast cells in rat intestine. Cell and Tissue Research 324, 353-600.

140. Holt S, Heading RC, Carter DC, Prescott LF \& Tothill P (1979) Effect of gel fibre on gastric emptying and absorption of glucose and paracetamol. Lancet 1, 636-639.

141. Moran TH, Smedh U, Kinzig KP, Scott KA, Knipp S \& Ladenheim EE (2005) Peptide YY(3-36) inhibits gastric emptying and produces acute reductions in food intake in rhesus monkeys. Am J Physiol 288, R384-R388.

142. Batterham RL, Cowley MA, Small CJ, Herzog H, Cohen MA, Dakin CL, Wren AM, Brynes AE, Low MJ, Ghatei MA, Cone RD \& Bloom SR (2002) Gut hormone PYY(3-36) physiologically inhibits food intake. Nature 418, 650-654.

143. Woods SC (2005) Signals that influence food intake and body weight. Physiol Behav 86, 709-716.

144. Bueno L, Praddaude F, Fioramonti J \& Ruckebusch Y (1981) Effect of dietary fiber on gastrointestinal motility and jejunal transit time in dogs. Gastroenterology 80, 701-707.

145. Lundberg JM, Tatemoto K, Terenius L, Hellstrom PM, Mutt V, Hokfelt T \& Hamberger B (1982) Localization of peptide YY (PYY) in gastrointestinal endocrine cells and effects on intestinal blood flow and motility. Proc Natl Acad Sci USA 79, 4471-4475.

146. Houpt KA (1982) Gastrointestinal factors in hunger and satiety. Neurosci Biobehav Rev 6, 145-164.

147. Lin HC, Zhao XT, Chu AW, Lin YP \& Wang L (1997) Fibersupplemented enteral formula slows intestinal transit by intensifying inhibitory feedback from the distal gut. Am J Clin Nutr 65, 1840-1844.

148. Roberfroid M (1993) Dietary fiber, inulin, and oligofructose: a review comparing their physiological effects. Crit Rev Food Sci Nutr 33, 103-148.

149. Louis-Sylvestre J \& Le Magnen J (1980) A fall in blood glucose level precedes meal onset in free-feeding rats. Neurosci Biobehav Rev 4, 13-15.

150. Campfield LA, Brandon P \& Smith FJ (1985) On-line continuous measurement of blood glucose and meal pattern in free-feeding rats: the role of glucose in meal initiation. Brain Res Bull 14, 605-616. 
151. Campfield LA, Smith FJ, Rosenbaum M \& Hirsch J (1996) Human eating: evidence for a physiological basis using a modified paradigm. Neurosci Biobehav Rev 20, 133-137.

152. Campfield LA \& Smith FJ (2003) Blood glucose dynamics and control of meal initiation: a pattern detection and recognition theory. Physiol Rev 83, 25-58.

153. Cherbut C (2003) Motor effects of short-chain fatty acids and lactate in the gastrointestinal tract. Proc Nutr Soc 62, 95-99.

154. Bleiberg B, Beers TR, Persson M \& Miles JM (1992) Systemic and regional acetate kinetics in dogs. Am J Physiol 262, E197-E202.

155. Rérat A (1996) Influence of the nature of carbohydrate intake on the absorption chronology of reducing sugars and volatile fatty acids in the pig. Reprod Nutr Dev 36, 3-19.

156. Wren AM, Seal LJ, Cohen MA, Brynes AE, Frost GS, Murphy KG, Dhillo WS, Ghatei MA \& Bloom SR (2001) Ghrelin enhances appetite and increases food intake in humans. J Clin Endocrinol Metab 86, 5992-5995.

157. Kojima M, Hosoda H, Date Y, Nakazato M, Matsuo H \& Kangawa K (1999) Ghrelin is a growth-hormone-releasing acylated peptide from stomach. Nature 402, 656-660.

158. van der Lely AJ, Tschöp M, Heiman ML \& Ghigo E (2004) Biological, physiological, pathophysiological, and pharmacological aspects of ghrelin. Endocr Rev 25, 426-457.

159. Cummings DE, Purnell JQ, Frayo RS, Schmidova K, Wisse BE \& Weigle DS (2001) A preprandial rise in plasma ghrelin levels suggests a role in meal initiation in humans. Diabetes 50, 1714-1719.

160. Delzenne NM, Cani PD, Daubioul C \& Neyrinck AM (2005) Impact of inulin and oligofructose on gastrointestinal peptides. Br J Nutr 93, S157-S161.

161. Butterwick RF \& Markwell PJ (1997) Effect of amount and type of dietary fiber on food intake in energy-restricted dogs. Am J Vet Res 58, 272-276.

162. Jewell DE \& Toll PW (1996) Effects of fiber on food intake in dogs. Vet Clin Nutr 3, 115-118.

163. Jackson JR, Laflamme DP \& Owens SF (1997) Effects of dietary fiber content on satiety in dogs. Vet Clin Nutr 4, $130-134$.

164. Pappas TN, Melendez RL \& Debas HT (1989) Gastric distension is a physiologic satiety signal in the dog. Dig Dis Sci 34, 1489-1493.

165. Howard MD, Kerley MS, Sunvold GD \& Reinhart GA (2000) Source of dietary fiber fed to dogs affects nitrogen and energy metabolism and intestinal microflora populations. Nutr Res 20, 1473-1484.

166. Russell J \& Bass P (1985) Canine gastric emptying of fiber meals: influence of meal viscosity and antroduodenal motility. Am J Physiol 249, G662-G667.

167. Murray SM, Patil AR, Fahey GC Jr, Merchen NR, Wolf BW, Lai C-S \& Garleb KA (1999) Apparent digestibility and glycaemic responses to an experimental induced viscosity dietary fibre incorporated into an enteral formula fed to dogs cannulated in the ileum. Food Chem Toxicol 37, 47-56.

168. Massimino SP, McBurney MI, Field CJ, Thomson AB, Keelan M, Hayek MG \& Sunvold GD (1998) Fermentable dietary fiber increases GLP-1 secretion and improves glucose homeostasis despite increased intestinal glucose transport capacity in healthy dogs. $J$ Nutr 128, $1786-1793$.

169. Daniel EE, Anvari M, Fox-Threlkeld JE \& McDonald TJ (2002) Local, exendin-(9-39)-insensitive, site of action of GLP-1 in canine ileum. Am J Physiol 283, G595-G602.

170. Kumar D, Phillips SF \& Brown ML (1988) Reflux from ileum to colon in the dog. Role of external ligamentous attachments. Dig Dis Sci 33, 345-352.
171. Pappas TN, Debas HT, Chang AM, Taylor IL \& Peptide YY (1986) Peptide YY release by fatty acids is sufficient to inhibit gastric emptying in dogs. Gastroenterology 91, 1386-1389.

172. Fahey GC Jr, Flickinger AE, Grieshop CM \& Swanson KS (2004) The role of dietary fibre in companion animal nutrition. In Dietary Fibre: Bio-active Carbohydrates for Food and Feed, pp. 295-328 [JM Kamp, NG Asp, J Miller and G Schaafsma, editors]. Wageningen, The Netherlands: Wageningen Academic Publishers.

173. Sunvold GD, Hussein HS, Fahey GC Jr, Merchen NR \& Reinhart GA (1995) In vitro fermentation of cellulose, beet pulp, citrus pulp, and citrus pectin using fecal inoculum from cats, dogs, horses, humans, and pigs and ruminal fluid from cattle. J Anim Sci 73, 3639-3648.

174. Butine TJ \& Leedle JA (1989) Enumeration of selected anaerobic bacterial groups in cecal and colonic contents of growing-finishing pigs. Appl Environ Microbiol 55, $1112-1116$.

175. Williams BA, Bosch M, Houdijk JGM \& Van der Camp Y (1997) Differences in fermentative capabilities of flora from different areas of porcine GIT. In Proceedings of the 48th EAAP Meeting, p. 133. Rome: European Association of Animal Production.

176. Diez M \& Istasse L (1997) Fibres alimentaires chez le chien: II. Effets sur la vidange gastrique et le transit gastro-intestinal (Food fibres in the dog II. Effects on gastric draining and gastrointestinal transit). Ann Méd Vét 141, 27-37.

177. Iwanaga Y, Wen J, Thollander MS, Kost LJ, Thomforde GM, Allen RG \& Phillips SE (1998) Scintigraphic measurement of regional gastrointestinal transit in the dog. Am J Physiol 275, G904-G910.

178. Bruce SJ, Guilford WG, Hedderley DI \& McCauley M (1999) Development of reference intervals for the large intestinal transit of radiopaque markers in dogs. Vet Radiol Ultrasound 40, 472-476.

179. Bugaut M (1987) Occurrence, absorption and metabolism of short chain fatty acids in the digestive tract of mammals. Comp Biochem Physiol B 86, 439-472.

180. Stevens EC \& Huma ID (1998) Contributions of microbes in vertebrate gastrointestinal tract to production and conservation of nutrients. Physiol Rev 78, 393-427.

181. Pouteau E, Nguyen P, Ballevre O \& Krempf M (2003) Production rates and metabolism of short-chain fatty acids in the colon and whole body using stable isotopes. Proc Nutr Soc 62, 87-93.

182. Pouteau E, Frenais R, Dumon H, Noah L, Martin L \& Nguyen P (2005) Colonic fermentation of inulin increases whole-body acetate turnover in dogs. J Nutr 135, 2845-2851.

183. Yokoyama M, Nakahara K, Kojima M, Hosoda H, Kangawa K \& Murakami N (2005) Influencing the between-feeding and endocrine responses of plasma ghrelin in healthy dogs. Eur J Endocrinol 152, 155-160.

184. Diez M, Hornick JL, Baldwin P, Eenaeme CV \& Istasse L (1998) The influence of sugar-beet fibre, guar gum and inulin on nutrient digestibility, water consumption and plasma metabolites in healthy beagle dogs. Res Vet Sci $\mathbf{6 4}$, 91-96.

185. Bourreau J, Hernot D, Bailhache E, Weber M, Ferchaud V, Biourge V, Martin L, Dumon H \& Nguyen P (2004) Gastric emptying rate is inversely related to body weight in dog breeds of different sizes. J Nutr 134, S2039-S2041.

186. Weber MP, Hernot D, Nguyen PG, Biourge VC \& Dumon HJ (2004) Effect of size on electrolyte absoprtion rates and fermentative activity in dogs. J Anim Physiol Anim Nutr 88, $356-365$.

187. Grimmett A \& Sillence MN (2005) Calmatives for the excitable horse: a review of l-tryptophan. Vet J 170, 24-32. 